\title{
Women's lives and rapid fertility decline: Some lessons from Bangladesh and Egypt
}

Sajeda Amin

Population Council

Cynthia B. Lloyd

Population Council

Follow this and additional works at: https://knowledgecommons.popcouncil.org/departments_sbsr-pgy

Part of the Demography, Population, and Ecology Commons, Family, Life Course, and Society Commons, and the International Public Health Commons How does access to this work benefit you? Let us know!

\section{Recommended Citation}

Amin, Sajeda and Cynthia B. Lloyd. 1998. "Women's lives and rapid fertility decline: Some lessons from Bangladesh and Egypt," Policy Research Division Working Paper no. 117. New York: Population Council. Version of record: https://doi.org/10.1023/A:102003061 


\section{Women's Lives and Rapid Fertility D ecline: Some Lessons from Bangladesh and Egypt}

Sajeda Amin

Cynthia B. Lloyd

1998 No. 117 


\title{
Women's Lives and Rapid Fertility Decline: Some Lessons from Bangladesh and Egypt
}

\author{
Sajeda Amin
}

Cynthia B. Lloyd

Sajeda Amin is Associate, Policy Research Division, Population Council. Cynthia B. Lloyd is Director of Social Science Research, Policy Research Division, Population Council. Authors are listed in alphabetical order. They contributed equally to this paper. 


\begin{abstract}
In some of the more traditional parts of the world, fertility is falling steadily, sometimes rapidly, in environments where women's lives remain severely constrained. The recent experiences of Bangladesh and Egypt, both predominantly Muslim countries, are illustrative in this regard. Since the late 1970s, rural and urban areas in both countries have experienced steady declines in fertility, with recent declines in rural Bangladesh similar to those in rural Egypt, despite lower levels of development and higher rates of poverty. This paper provides an in-depth exploration of the demographic transition in these two societies as seen through the dual lens of society-wide gender systems and a range of relevant state policies. It addresses three basic questions: (1) have measurable improvements in economic opportunities for women been a factor in the fertility decline in either country?; (2) have differences in gender systems at the societal level provided a more favorable environment for fertility decline in Bangladesh in comparison to Egypt, despite the former's more modest economic achievements?; (3) in what ways can the development strategies adopted by the governments of Bangladesh and Egypt, with their very different implications for women's opportunities in contexts where personal autonomy remains limited, be seen as additional factors in explaining the similar rural fertility declines despite dissimilar economic circumstances? After reviewing the evidence, the paper concludes that neither differences in existing gender systems nor measurable changes in women's opportunities have been key factors in the notable demographic successes recorded in these two countries. Indeed, low levels of women's autonomy have posed no barrier to fertility decline in either country. However, there is a case to be made that Bangladesh's distinct approach to development, with considerable emphasis on reaching the rural poor and women and a strong reliance on nongovernmental institutions, may have played a part in accelerating the transition in that environment and in helping women to become more immediate beneficiaries of that process.
\end{abstract}

This material may not be reproduced in any form without written permission from the authors. 
In some of the more persistently traditional parts of the world, fertility is falling steadily, sometimes rapidly, in environments where women's lives remain severely constrained. The recent experiences of Bangladesh and Egypt, both predominantly Muslim countries, are illustrative in this regard. Both societies can be characterized as religiously and ethnically homogeneous and socially conservative. Their rural populations (55 percent of the total for Egypt, 82 percent for Bangladesh) shared roughly the same level of fertility of about six children per woman in the late 1970s and early 1980s. Since that time, rural and urban areas in both countries have experienced steady declines in fertility, with recent declines in rural Bangladesh similar to those in rural Egypt despite lower levels of development and higher rates of poverty. A fuller exploration of these two transitions reveals important differences in development styles and subtle differences in gender systems that may have implications for the future course of the transition and for the lives of women in these two settings, as well as in other settings where women's lives remain constrained.

For many years there has been a widely accepted view within the international population field that improvements in the status or position of women relative to men are critical elements, and possibly even necessary conditions, for significant fertility declines to occur in parts of the world that remain patriarchal and poor. This conviction, which has been articulated in increasingly strong language in successive international conferences on population, is most recently echoed in the language of the Programme of Action of the International Conference on Population and Development held in Cairo in 1994:

... improving the status of women also enhances their decision-making capacity at all levels in all spheres of life, especially in the area of sexuality and reproduction. This, in turn, is essential for the longterm success of population programmes. (United Nations 1994:25; emphasis added) 
These views have been supported and reinforced by the writings of wellknown scholars. For example, Caldwell (1982), Cain (1984), and Folbre (1983, 1996) have written persuasively about the ways in which patriarchal systems sustain high fertility. Karen Mason's (1985) well-articulated conceptual framework, which lays out the pathways through which women's status could affect fertility and mortality, has been highly influential in the field of demography and has inspired an extensive literature designed to test her hypotheses empirically.

During the 1970s and 1980s, researchers repeatedly documented, using cross-sectional data from representative surveys, consistent empirical associations between various commonly used proxies for women's status such as education and work status and their fertility, in a wide range of developing countries from different regions. Comprehensive reviews of these literatures can be found in Lloyd (1991) for work and Jejeebhoy (1995) for education. The implications of these studies were clear: improved educational and formal employment opportunities for women would lead to growing proportions of women completing primary schooling and going on to secondary schooling, and, somewhat later, would lead to greater numbers of women participating in modern-sector employment. These collective changes would be expected to push a larger proportion of women into the low fertility camp, with the result being a fertility transition.

More recently, much effort has gone into improved measurement of various dimensions of women's autonomy - a term that has gained favor over status because of its attention to underlying capabilities rather than to characteristics or outcomes - in order to develop a deeper understanding about the role of gender inequality in the fertility transition. Most researchers who use the term are interested in measuring women's access to and control over resources. Special data collection efforts have focused primarily on three aspects of female autonomy: (1) mobility, (2) women's role in household decisionmaking, and (3) control over resources. Major projects include the five-country Asian study spearheaded by 
Karen Mason and her colleagues (for example, Mason 1996) and studies by Morgan and his colleagues in India (Dharmalingam and Morgan 1996) and Nepal (Niraula and Morgan 1996; Morgan and Niraula 1995). Studies of female autonomy in Egypt (Nawar, Lloyd, and Ibrahim 1995; Govindasamy and Malhotra 1996; Kishor 1997) and Bangladesh (Balk 1994, 1997) have found, consistent with the empirical literature cited above, that women's personal autonomy, however measured, is typically associated with lower fertility. Again, the implication of these findings is that improvements in women's autonomy would lead to fertility decline.

The major insight from this newer literature relates to the importance of gender systems as they operate at the level of the community or the society for women's personal autonomy. If a particular gender system severely constrains women's autonomy through social norms, laws, and policies, even highly educated women may have limited personal autonomy. By contrast, in environments where women share with men equal entitlements that reflect social values and are reinforced by law and policy, poor or uneducated women can have sufficient personal autonomy to achieve their reproductive and other goals despite a lack of personal resources. Studies in India (Basu 1992; Dharmalingam and Morgan 1996) and Bangladesh (Balk 1994, 1997), as well as comparative studies in India, Malaysia, Pakistan, Philippines, and Thailand (for example, Mason 1996), document how these systems work and their importance in explaining individual variations in measured autonomy.

In the meanwhile, however, recent demographic trends have outpaced improvements in women's status or autonomy whether measured at the individual or community level. Many fertility declines have taken off in relatively poor settings, with the pace of decline often proceeding most rapidly among the least educated women (for example, Weinberger, Lloyd, and Blanc 1989). Indeed, in a study of fertility trends in five Latin American and two African countries, the 
United Nations (1995a) found that declines in fertility within education groups explained the overwhelming proportion of fertility change in all countries but Peru; improvements in the education of women over time explained only 11-12 percent of the decline in Kenya and Senegal and from 33 to 60 percent of the decline in Latin America. And in this paper, we show that recent fertility declines in Bangladesh and Egypt have been at least as rapid among the least educated women as among the elite. Furthermore, these are settings where one gender system operates society-wide and where women's autonomy remains extremely low. While recent experience is not necessarily inconsistent with the empirical associations established in the cross-section between women's status or autonomy and fertility, "History shows that the persistence of gender inequality does not preclude the occurrence of a demographic transition" (Population Council 1996: 2; emphasis added).

In her recent presidential address to the Population Association of America, Mason (1997a) summarized the historical and contemporary experience with fertility decline: "Fertility transitions occur under a variety of institutional, cultural and environmental conditions" (p. 449). As a follow-up to this overarching paper on fertility transitions, Mason and Bulatao (1998) carefully detail the ways that pre-existing gender systems can have conditioning effects on the timing and pace of the transition. However, they appear to view these as second-order effects rather than as primary factors in explaining the timing and pace of fertility decline. They point out that the most important potential effect of gender systems on the pace of fertility transitions relates to the costs of fertility regulation. In settings where fertility regulation is achieved primarily through modern means, the speed of the transition may be accelerated if women gain access to knowledge, become more mobile, and have greater control over resources, all factors that reduce the personal costs of acquiring and using modern means of fertility regulation. Nevertheless, Mason and Bulatao (1998) point out that other factors may intervene to ensure a fertility transition even when women's opportunities 
are severely constrained. Family planning programs, such as the one in Bangladesh, that deliver family planning services to the door can overcome such obstacles (Arends-Kuenning 1997). A less recognized but equally important role of the doorstep delivery of services may be that it brings women in contact with other women from outside their usual social network, thus enhancing social learning and social influence, potentially further speeding the fertility transition in the manner described by Rosero-Bixby and Casterline (1994) as the process of interaction diffusion.

Research on community-based gender systems has relied primarily on the aggregation of individual reports to create characterizations of gender systems for the community. There has been less emphasis on collecting data at the community or state level about social institutions that may constitute "gender-specific environmental parameters" which enhance or impair women's bargaining power within the home (Folbre 1997). Indeed, women's operational autonomy may depend not only on the elements that traditionally constitute measurements of personal autonomy such as access to and control over resources but also on support from community institutions, such as nongovernmental organizations (NGOs), or from the state. Agarwal (1997) illustrates the potential importance of NGOs in enhancing women's bargaining power at the community level in environments where women have little such power within the family. Through programs that create women-to-women connections within the context of a credit group or as a result of the relationship between the village family planning worker and her clients, information is shared, solidarity is created, and common interests are addressed. As Balk (1997) notes, "programmes aimed solely at giving individual women options would be insufficient; they would be more effective by incorporating other household and community members" (p. 170).

Indeed, if it is at the social or state level that gender systems are most salient in their implications for demographic change, then none of the evidence reviewed here can be used to prove or disprove the demographic importance of 
gender or gender systems. While we know that fertility decline can occur while women's autonomy, as measured at the individual level, remains low, we do not know how important social and state institutions may be in defining the opportunity structures that surround women and in enhancing their collective autonomy at a broader community level. Mason (1997b), extending her earlier work on women's status $(1985,1986)$, has pointed out the particular difficulties we face when trying to study these relationships. One of these difficulties has to do with the aggregated nature of demographic change. As a result, the impact of changes in gender systems on demographic outcomes can be determined only through the observation of successive cohorts. Mason suggests that the ideal study design would be a longitudinal study of two populations that were initially similar in their demographic characteristics and gender systems but subsequently experienced differences in the evolution of their gender systems as a result of state action and/or the emergence of a social or religious movement.

Following this line of thinking, we consider Bangladesh and Egypt to be ideal candidates for such a comparison. The countries share a common religion and similar gender systems. They have also experienced rapid rural fertility declines over the same time frame in the context of similar physical surroundingsdense settlement patterns along rivers and their deltas. Nonetheless, Bangladesh has achieved its fertility decline under much less favorable economic circumstances. Furthermore, state development policies, despite similar goals, have been articulated and implemented quite differently in Bangladesh and Egypt. Given these differences, a comparison offers the possibility of exploring whether these differences in state policies may have mediated the relationship between socioeconomic development and fertility decline through their effects on the opportunity structures of the women who have changed their fertility behavior. Relevant state policies would include not only development and population programs but also responses to social changes such as rising religious fundamentalism. 
A comparison of Bangladesh and Egypt has one further advantage. These countries, while sharing much else in common, share no common borders. Usually, they are compared with their more proximate neighbors in South Asia or in the Middle East and North Africa, respectively, because of shared cultural heritage (see Fargues 1997; Das Gupta and Narayana 1997). However, given evidence of social influence across the borders of contiguous states leading to regional homogeneity in demographic trends (Coale and Watkins 1986; Casterline 1998; Bongaarts and Watkins 1996), it is more difficult to see trends within South Asia or among neighboring countries in the Middle East and North Africa as occurring entirely independently of each other.

The paper addresses three questions: (1) Have measurable improvements in economic opportunities for women been a factor in the fertility decline in either country? (2) Have differences in gender systems at the societal level provided a more favorable environment for fertility decline in Bangladesh in comparison to Egypt, despite the former's more modest economic achievements? (3) In what ways can the development strategies adopted by the governments of Bangladesh and Egypt, with their very different implications for women's opportunities in contexts where personal autonomy remains limited, be seen as additional factors in explaining the similar rural fertility declines despite dissimilar economic circumstances? In order to address the first question, we set the contemporary demographic profile of each country into the context of recent changes in fertility and in women's opportunities in order to see to what extent measurable changes in women's lives are associated with demographic change. To address the second question, we describe the key features of gender systems in Bangladesh and Egypt that are broadly characteristic of each society as a whole. From this description and review, we identify key similarities and differences in the lives of Bangladeshi and Egyptian women that have likely conditioned the fertility transition in each country. To address the third question, we broaden our 
angle of vision to examine various dimensions of change at the national level to see what implications these changes may have had for women's opportunities and for the pace of fertility change. In concluding the paper, we speculate about the implications of these two settings for development strategies in other contexts where gender systems continue to limit women's autonomy but where policy goals include commitments to improve women's lives and to reduce rates of population growth.

\section{RECENT TRENDS IN FERTILITY AND THEIR DETERMINANTS}

\section{Fertility}

Egypt is a highly urbanized society while Bangladesh remains largely rural. The United Nations estimates that 45 percent of Egypt's population lives in urban areas, and this percentage has been roughly constant for at least two decades (United Nations 1995b). In 1995, 18 percent of the population in Bangladesh was estimated to live in urban areas, doubling over the previous 20 years from a rate of 9 percent in 1975 (United Nations 1995b). Since differences in overall fertility can be driven by levels of urbanization alone, we compare Egypt and Bangladesh by urban and rural characteristics separately, with a particular emphasis on the rural setting.

Bongaarts and Watkins (1996) date the start of the Egyptian transition to 1968 and the start of the Bangladeshi transition to 1981, defining the onset of the fertility transition as a decline of 10 percent from pretransitional levels. Casterline (1998), using the same UN estimates, dates the start of the transition in Egypt to 1960-65 and the start of the transition in Bangladesh to 1970-75, commencing from the peak from which fertility began to decline. Recent in-depth analyses of Egypt (Fargues 1997) and Bangladesh (Dyson 1996) using crude birth rates as 
the indicator place the start of the fertility decline earlier in both Egypt and Bangladesh — as far back as the early 1960s. It is likely that this earlier decline in birth rates is related to delayed marriages rather than to birth control within marriage (Coale 1988; Huq and Cleland 1990). Although none of these analyses of trends is broken down by rural and urban area, it is likely that much of the early decline in Egypt was confined to urban areas. Rural fertility in Egypt was estimated at 6.1 in 1980, roughly the same level as rural fertility in Bangladesh in 1975. While rural fertility levels were possibly higher in Egypt than in Bangladesh at that time, nonetheless it appears that rural fertility was relatively high in both settings into the early 1980s. This, then, becomes a useful starting point for the assessment of trends (see Figure 1).

Table 1 shows the latest data on the demographic situation in Bangladesh and Egypt. In both rural and urban areas, current fertility estimates for Egypt exceed comparable estimates for Bangladesh. The rural fertility rate of 4.2 children per woman for Egypt compares with 3.4 in Bangladesh. The urban fertility rate of 3.0 in Egypt compares with an urban rate of 2.1 in Bangladesh. Ideal family size is lower in Bangladesh than in Egypt, suggesting that lower fertility is partially explained by a stronger motivation to control fertility. Contraceptive use rates are also consistently higher in Bangladesh than in Egypt in both rural (7 percentage points) and urban areas (6 percentage points). Rates of unmet need for contraception are similar in both countries and consistent with contraceptive use rates.

Differences in contraceptive use rates between the two countries, however, cannot explain the entire difference in fertility, particularly given the much lower mean age at marriage in Bangladesh. ${ }^{1}$ In fact, couples in Bangladesh would need considerably higher levels of contraceptive use than implied by cross-national estimates to compensate for the higher duration of exposure to the risk of childbearing brought about by women's much earlier age at marriage. The median ages at marriage in Bangladesh for women aged 25-49 in 1996 were 13.8 and 
Figure 1 Trends in Fertility and Contraceptive Use in Rural and Urban Areas of Bangladesh and Egypt
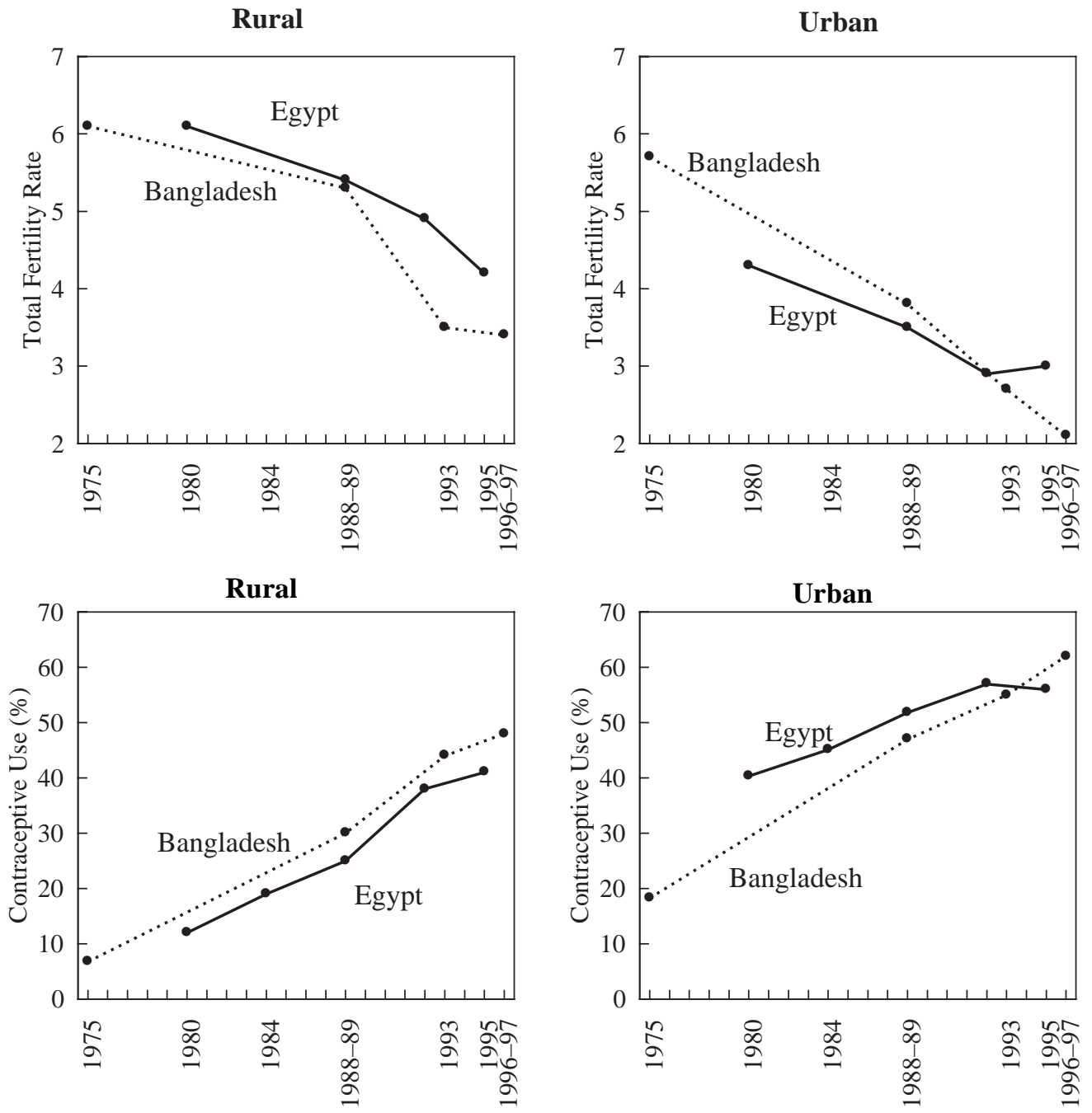

SOURCES: TFR:

1975, 1980: Ashurst, Balkaran, and Casterline 1984

Contraceptive Use:

Egypt: El-Zanaty et al. 1996

Bangladesh: Tabulated from Surveys

1988-1995, Egypt: El-Zanaty et al. 1996

1989, Bangladesh: Huq and Cleland 1990

1993: Mitra et al. 1994 
Table 1 Demographic Characteristics: Bangladesh 1996-97 and Egypt 1995

\begin{tabular}{|c|c|c|c|c|}
\hline & \multicolumn{2}{|c|}{ Rural } & \multicolumn{2}{|c|}{ Urban } \\
\hline & Bangladesh & Egypt & Bangladesh & Egypt \\
\hline Total fertility rate & 3.4 & 4.2 & 2.1 & 3.0 \\
\hline $\begin{array}{l}\text { Contraceptive use (percent of } \\
\text { currently married women } 15-49 \text { ) }\end{array}$ & 48 & 41 & 62 & 56 \\
\hline $\begin{array}{l}\text { Median age at first marriage } \\
\text { (ever-married women } 25-49)\end{array}$ & 13.8 & 17.9 & 15.3 & 21.0 \\
\hline $\begin{array}{l}\text { Median length of amenorrhea } \\
\text { (months) }\end{array}$ & 8.8 & 7.7 & 5.6 & 3.3 \\
\hline $\begin{array}{l}\text { Median duration of breastfeeding } \\
\text { (months) }\end{array}$ & 32.8 & 19.5 & 32.8 & 17.9 \\
\hline Infant mortality rate $($ age $<1)$ & 91 & 87 & 73 & 51 \\
\hline Child mortality rate (ages $0-5$ ) & 131 & 116 & 96 & 65 \\
\hline $\begin{array}{l}\text { Unmet need for spacing or limiting } \\
\text { (percent of currently married } \\
\text { women } 15-49 \text { ) }\end{array}$ & 17 & 20 & 10 & 11 \\
\hline Ideal desired family size & 2.5 & 3.0 & 2.3 & 2.6 \\
\hline Muslim population (percent) ${ }^{\mathrm{a}}$ & 89 & 96 & 90 & 93 \\
\hline Percent of children 7-12 in school ${ }^{a}$ & 78 & 79 & 77 & 93 \\
\hline $\begin{array}{l}\text { Percent of children } 12-15 \text { with } \\
4+\text { years of schooling }\end{array}$ & 52 & 74 & 64 & 90 \\
\hline
\end{tabular}

${ }^{a}$ Tabulated directly from Bangladesh DHS (1996-97) and Egypt DHS (1995).

SOURCES: El-Zanaty et al. 1996; Mitra et al. 1997

15.3 in rural and urban areas respectively, compared to 17.9 and 21 in rural and urban Egypt. ${ }^{2}$ Even the longer breastfeeding durations in Bangladesh are not sufficient to explain women's surprisingly low levels of fertility in relationship to Egypt. Instead, higher rates of abortion in Bangladesh relative to Egypt are the most likely explanation. Bangladesh is unusual in having widely available services for early termination of pregnancy by menstrual regulation. More impor- 
tantly, unlike Egypt, where abortion services are not widely available and can be obtained from doctors only under limited circumstances, menstrual regulation in Bangladesh is highly accessible because the procedure is conducted by female paramedics and is available in rural health centers free of charge (Amin 1996).

\section{Socioeconomic Conditions}

At the societal level, various factors have been linked with the onset and pace of fertility decline in recent as well as earlier assessments of fertility transitions. ${ }^{3}$ While the emphases may vary from author to author, three factors that feature prominently in all theoretical and empirical analyses of the fertility transition are economic development, mortality, and social effects variously named social interaction, diffusion, or ideational change. We briefly review evidence for each of these factors in turn.

A comparison of economic development in Bangladesh and Egypt would lead us to expect that Egypt would be further along in the demographic transition than Bangladesh. With a 1994 real per capita income of US\$3,846, Egypt is considerably wealthier than Bangladesh with a per capita income of US\$962 in the same year (UNDP 1997). The ratio of relative per capita incomes was about the same 25 years ago at considerably lower levels of per capita income (United Nations 1985). Recent assessments by UNDP (1996) also put Egypt substantially higher in the ranking on the gender development index, which assesses gender differences in all the constituent elements of the human development index (income, education, and mortality). Furthermore, the percentage of population below the poverty line according to a newly constructed "human" poverty index, which encompasses factors other than income, ${ }^{4}$ is estimated at 34.8 percent for Egypt and 48.3 percent for Bangladesh (UNDP 1997), supporting the assumption that the income differentials translate to higher levels of poverty in Bangladesh. However, the gap is not as wide as might be expected based on more 
conventional measures of poverty and based on income alone. ${ }^{5}$ Finally, relative levels of per capita income and poverty suggest that there is much greater inequality in Egypt than in Bangladesh.

Overall levels of adult educational attainment are higher in Egypt than in Bangladesh, although rates of enrollment for children of primary school age are similar (see Table 1). High enrollment in Bangladesh may be attributable to several recent education policies, including enrollment drives, incentive schemes, and non-formal education programs. The relatively low proportion of adolescents (aged 12-15) who have at least four years of schooling shows, however, that, at least in rural Bangladesh, current levels of enrollment are a recent phenomenon. The percentage of 12-15-year-olds with at least four years of education is 52 percent in rural Bangladesh compared to 74 percent in rural Egypt.

Several other factors have potential importance because of their implications for overall levels of development as well as for diffusion or social interaction effects. These include urbanization and population density. A substantial urban economy in Egypt provides opportunities to the surrounding rural areas through labor migration. Thus, the level of urbanization is likely to exert an independent influence on fertility in rural areas by creating higher levels of aspirations through the urban influence. On the basis of the level of urbanization for the country as a whole, fertility levels should be lower in Egypt relative to the considerably more rural Bangladesh. On the other hand, the two countries have similarly high levels of population density. Bangladesh averages 825 persons per square kilometer and Egypt averages $988 .^{6}$

Finally, mortality rates in Egypt are substantially lower than in Bangladesh in both rural and urban areas (except in the case of the infant mortality rates in rural areas, where the gap has almost closed between the two countries), but the difference is generally greater for urban areas. For all of these underlying reasons, we would expect Egypt to be further along in the fertility transition than Bangladesh. 


\section{Women's Opportunities}

A comparison between the two countries of some common measures of women's status as well as a few indicators of women's autonomy suggests that women in both settings still fare extremely poorly, particularly in rural areas, by international standards (see Table 2). Indeed, by breaking down our comparisons into rural and urban, we see how surprisingly similar the situation of Egyptian and Bangladeshi women appears in many respects. First, looking at household structure, we find similar levels of reported female headship: 9 percent in both rural and urban Bangladesh and 12 percent in Egypt. Women's relationships within the household are also similar: 73 percent of currently married rural women (aged 15-49) were wives of the household head in both Bangladesh and Egypt, and 78 and 85 percent were wives of the household head in urban Bangladesh and Egypt respectively.

Among rural women, 57 percent in Bangladesh and 59 percent in Egypt have no schooling, and only 31 and 30 percent have at least four years of schooling. While the percent of women working for cash is higher in rural Bangladesh than rural Egypt, only a small minority of women in either setting is engaged in remunerative activities. Indeed, only 23 percent of rural women in Bangladesh reported working for cash compared to less than half that fraction (11 percent) in Egypt. In urban areas, women fare somewhat better. Thirty-six and 27 percent of urban women in Bangladesh and Egypt respectively have no education, while 55 and 66 percent have at least four years. A noticeable improvement in access to education is evident by contrasting women to girls. Between 68 and 94 percent of girls aged 7-12 are enrolled in school in rural and urban areas in the two countries.

Only 9-12 percent of currently married rural women report being primarily responsible for decisionmaking related to the family budget, which is more consistent with rates of cash work in Egypt than in Bangladesh. In urban areas of both countries, between 21 and 25 percent of women work for cash and 16 per- 
Table 2 Current Indicators of Women's Status and Autonomy (in Percent): Bangladesh 1996-97 and Egypt 1995

$\frac{\text { Rural }}{\text { Bangladesh Egypt }} \quad \frac{\text { Urban }}{\text { Bangladesh Egypt }}$

\section{Household Structure}

Female-headed households

9

12

9

12

Currently married women

(15-49), wife of head

73

73

78

85

\section{Education}

Ever-married women (15-49)

with no education

59

36

27

Ever-married women (15-49) with

at least 4 years of education

31

30

55

66

Girls (7-12) enrolled in school

79

68

77

94

Ever-married women (15-49)

with husband having 5 or more

years of education

17

28

21

25

\section{Work}

Ever-married women (15-49)

working for cash at time of survey

23

11

25

21

\section{Autonomy}

Currently married women (15-49) taking primary role in decisionmaking about family budget

Currently married women (15-49) reporting ability to go out shopping alone $7^{\mathrm{a}}$

$63^{c}$

$27^{\mathrm{a}}$ $78^{c}$

NOTE: Unless otherwise noted, tabulated from standard recode tapes of Bangladesh DHS (1996-97) and Egypt DHS (1995).

${ }^{\text {a }}$ Huq and Cleland 1990

${ }^{\mathrm{b}}$ El-Zanaty et al. 1993

'Sayed et al. 1989 
cent take a primary role in decisionmaking about the family budget. The relatively high proportion of women working for cash in Bangladesh appears to be a recent phenomenon, and is discussed further below. The only striking difference between Bangladeshi and Egyptian women from these data can be seen in their reported degrees of mobility. Even in urban Bangladesh, only 27 percent of women report being able to go out shopping alone, whereas 78 percent of urban Egyptian women are able to do so. Mobility is relatively more restricted in rural areas in both countries, but the differences between women in the two countries remain substantial. The lower mobility of Bangladeshi women may help sustain the long breastfeeding durations that have been traditional in Bangladesh.

There are many economic, social, and political factors to consider in understanding what lies behind the ongoing demographic transitions in Bangladesh and Egypt. An in-depth analysis of the Bangladesh experience ruled out economic and social explanations in favor of a strong family planning program (Cleland et al. 1994). Recent analyses of the Egyptian experience reach strongly conflicting conclusions on the role of the family planning program relative to other socioeconomic changes in the recent fertility decline (Fargues 1997; Robinson and El-Zanaty forthcoming).

The contribution of women's schooling to fertility decline may be illustrative as a marker for the contribution of changing underlying characteristics. While there is some evidence that the levels of women's education have improved for younger cohorts and that, particularly in Bangladesh, the gender gap is narrowing for the youngest cohorts of women (see Figure 2), it is by no means clear that gains in educational attainment explain changing fertility. On the contrary, as shown in Table 3, the rise in contraceptive use has been at least as rapid among uneducated women as among women with higher education in both Bangladesh and Egypt. As a result educational differentials in contraceptive use and fertility have diminished rapidly. 
Figure 2 Percent of Males and Females with 4 or More Years of Education by Five-Year Age Groups: Rural and Urban Areas of Bangladesh 1996-97 and Egypt 1995
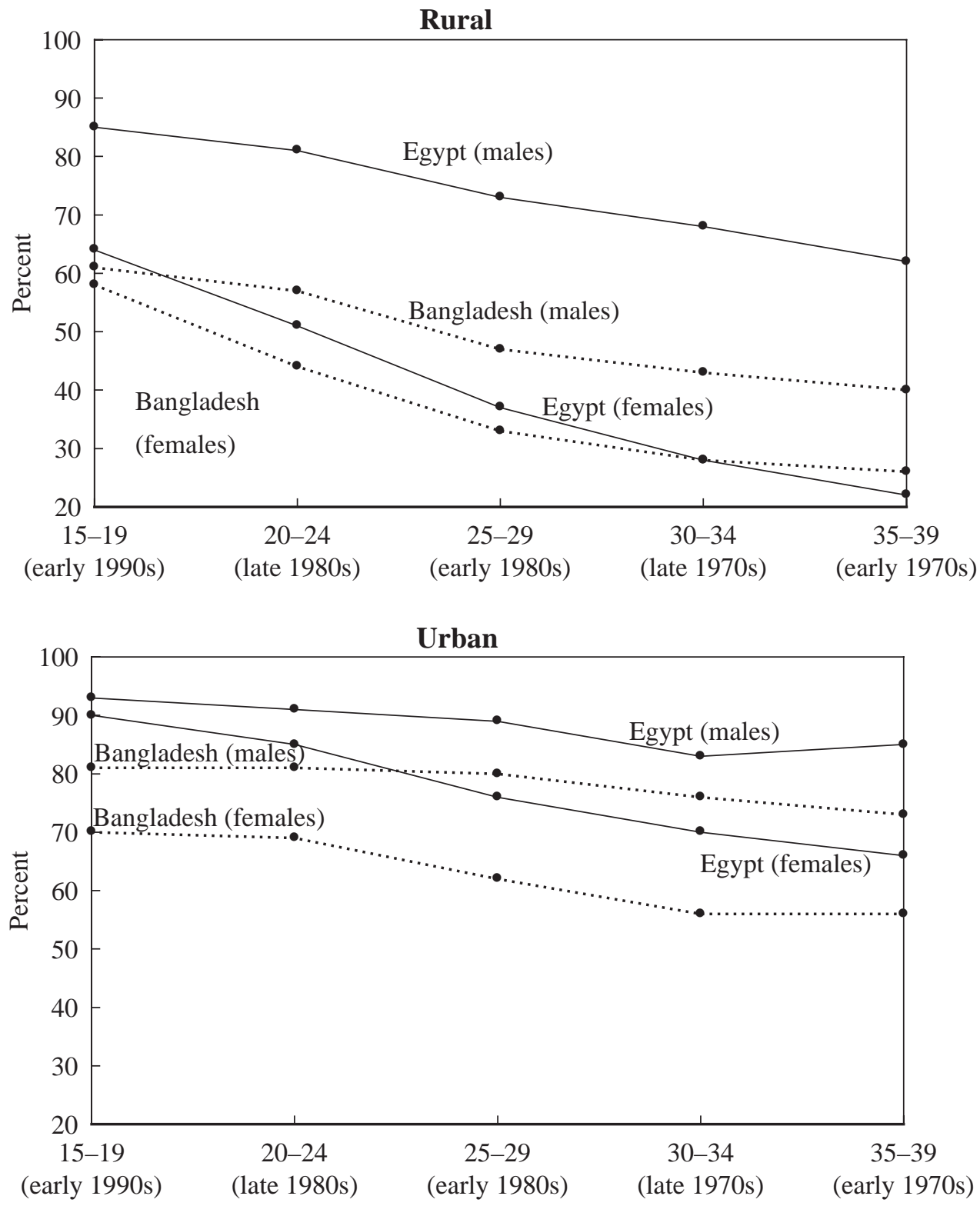

Note: Cohorts attending primary school in years specified 
Table 3 Contraceptive Prevalence Rates (CPR) and Total Fertility Rates (TFR) by Women's Educational Level: Bangladesh 1975-96 and Egypt 1980-95

\begin{tabular}{|c|c|c|c|c|c|c|c|c|}
\hline \multirow[b]{3}{*}{ Educational level } & \multicolumn{6}{|c|}{ Bangladesh } & & \\
\hline & \multicolumn{2}{|c|}{1975} & \multicolumn{2}{|c|}{1989} & \multicolumn{2}{|c|}{ 1993-94 } & \multicolumn{2}{|c|}{1996} \\
\hline & CPR & TFR $^{\mathrm{a}}$ & & $\begin{array}{c}\text { TFR } \\
1984-88\end{array}$ & CPR & $\begin{array}{c}\text { TFR } \\
1991-94\end{array}$ & CPR & $\begin{array}{c}\text { TFR } \\
\text { 1993-96 }\end{array}$ \\
\hline None & 7 & 6.1 & 28 & 4.5 & 41 & 3.8 & 46 & 3.9 \\
\hline Incomplete primary & 一 & 6.4 & $33^{\mathrm{b}}$ & $4.4^{\mathrm{b}}$ & 46 & 3.4 & 51 & 3.3 \\
\hline Primary completed & 14 & 6.7 & $39^{b}$ & $4.0^{\mathrm{b}}$ & 46 & 3.3 & 51 & 3.0 \\
\hline Secondary & 27 & 5.0 & 49 & 3.3 & 56 & 2.6 & 56 & 2.1 \\
\hline
\end{tabular}

\begin{tabular}{|c|c|c|c|c|c|c|c|c|}
\hline \multirow[b]{3}{*}{ Educational level } & \multicolumn{8}{|c|}{ Egypt } \\
\hline & \multicolumn{2}{|c|}{1980} & \multicolumn{2}{|c|}{1988} & \multicolumn{2}{|c|}{1992} & \multicolumn{2}{|c|}{1995} \\
\hline & $\mathbf{C P R}^{\mathrm{a}} \mathbf{T}$ & $\mathrm{MFR}^{\mathrm{a}, \mathrm{c}}$ & CPR & TFR & CPR & TFR & CPR & TFR \\
\hline None & 17 & 6.5 & 28 & 5.7 & 38 & 5.0 & 41 & 4.6 \\
\hline Lower primary & 25 & 6.4 & 43 & 5.1 & 54 & 4.0 & 51 & 3.7 \\
\hline $\begin{array}{l}\text { Primary through } \\
\text { secondary }\end{array}$ & $32-35$ & 6.2 & 52 & 3.8 & 56 & 3.0 & 51 & 3.1 \\
\hline $\begin{array}{l}\text { Completed secondary } \\
\text { or higher }\end{array}$ & $66-69$ & 3.8 & 53 & 3.2 & 58 & 2.9 & 57 & 3.0 \\
\hline
\end{tabular}

a United Nations 1987.

b The 1989 Bangladesh Fertility Survey used lower primary (1-4) and upper primary (5-6). ${ }^{c}$ WFS 1980 (Egypt) does not allow for the calculation of TFR. The total marital fertility rate (TMFR) is given instead.

SOURCES: El-Zanaty et al. 1993, 1996; Mitra et al. 1994, 1997; Sayed et al. 1989.

Taken together, this review would rule out improvements in the economic opportunities of reproductive-aged women, either as conventionally defined using measures of education and work or as recently defined using more subjective measures of women's autonomy, as a driving force behind the fertility decline or 
even as a catalytic factor speeding decline in Bangladesh and Egypt. Despite noticeable improvements in access to education for the current generation of children in both countries, levels of illiteracy in rural areas remain high among the very women who have participated in the countries' recent rapid fertility declines. Even in the mid-1990s, less than a third of reproductive-aged women in either rural Egypt or rural Bangladesh have completed four years of schooling, the level beyond which fertility rates typically decline in cross-sectional comparisons (Jejeebhoy 1995). At the same, time only a small minority of women in either setting is engaged in any form of directly remunerative work despite much lower fertility rates in the 1990 s.

\section{GENDER SYSTEMS}

Gender systems are inextricably entwined with family systems and must be understood in that context. The traditional division of familial responsibility between men and women is based on the complementarity of gender roles. There is considerable evidence of a gender-based household division of labor in both Bangladesh and Egypt (Naguib and Lloyd 1994; Govindasamy and Malhotra 1996; Amin 1997). Time-use data from rural Bangladesh suggest that men and women have completely separate spheres of responsibility: women spend most of their time in household chores and childcare, while men spend their time in agricultural or other income-earning activities (Amin 1997). While we do not have comparable time-use data for Egypt, attitudinal data suggest that women and men have separate spheres of influence in which they exercise significant power and authority. As might be expected, women's domains include household management, childcare, and reproduction (Govindasamy and Malhotra 1996). Furthermore, the corporate nature of the family in most Asian societies means that women's interests are strongly tied to the interests of the family (Cain 1984). Along a similar vein, it has been argued that, in the familial context in Egypt, both men and women 
value social interdependence more highly than autonomy (Nawar, Lloyd, and Ibrahim 1995). As a result, the gender-based division of roles makes for a highly interdependent structure within the family.

With common religious traditions but different cultures, the gender systems in these two societies have striking similarities and notable differences. Much has been written about the low status of women in both Egypt and Bangladesh (for example, Cain, Khanam, and Nahar 1979 for Bangladesh and Naguib and Lloyd 1994; Nawar, Lloyd, and Ibrahim 1995 for Egypt). In our discussion below, we explore the various ways the Egyptian and Bangladeshi gender systems manifest themselves through marriage, remunerative work, and the practice of seclusion.

\section{Marriage}

Several aspects of the Egyptian and Bangladeshi gender systems, particularly those derived from Islamic personal laws about marriage and the family, appear to be similar. Islamic laws grant unequal rights of divorce and inheritance to men and women. Men have the right to verbal divorce and polygamy. Women can seek divorce only if it is explicitly granted to her in the marriage contract. Women are not allowed to practice polygamy under any circumstances, although both men and women are allowed to remarry if divorced, deserted, or widowed. Marriage between kin is permitted in Islam. Women inherit half as much as their brothers from their parents. Wives inherit an eighth of a husband's property while a husband inherits all of his wife's property upon her death (Naguib and Lloyd 1994, Cain, Khanam, and Nahar 1979).

Although not codified in law, there are also broad similarities between Bangladesh and Egypt in customary practice with regard to marriage and family. As in most societies, residence is patrilocal and young couples start married life in or near the husband's parents' household. Egyptian society appears to show 
strong preference for within-kin marriages and endogamous marriages in general (Fernea 1985). While Bangladeshis do not appear to have the same strength of preference for kin relations in choice of marriage partners, most marriages show strong preference for within-village marriages with similar justification and implications as kin marriages. In an arranged marriage, a bride is more likely to be secure and happy when she is married within the family or the village because her neighbors are more likely to be familiar to her. There is some evidence in both Egypt and Bangladesh that brothers have de facto control over their sisters' inheritance. Women appear to give up their claim to parental property in exchange for visitation rights after marriage, or as a way of maintaining the right to return in case of divorce (Naguib and Lloyd 1994; Cain, Khanam, and Nahar 1979).

The incidence of polygyny is low in both Egypt and Bangladesh, despite its legality. Proportions of women currently divorced or ever-remarried are also similar in both settings. Proportions currently divorced were 1.9 percent in Bangladesh in 1993 and 1.4 percent in Egypt in 1992, and proportions married more than once were 7.3 and 5.4 percent respectively (Kishor and Neitzel 1996). The actual incidence of divorce is clearly higher than the rates recorded here. It is masked by tendencies to remarry soon after for those who are divorced, especially at young ages. In both settings, most of the relatively few divorces take place in the first few years of marriage (Barakat 1985; Mostafa et al. 1996).

One indication of gender inequality within marriage in both societies is the slight rise in the educational advantage of husbands relative to wives in a context in which the overall levels of schooling among marriageable young men and women are rising rapidly. The percentage of couples in which the husband has five or more years of schooling than the wife has risen from 15 percent in 1975 to 22 percent in 1996-97 in urban Bangladesh and from 17 percent in 1980 to 25 percent in 1995 in urban Egypt (see Table 4). In rural areas the increase has been particularly marked in Egypt, where it has risen to 28 percent. Obviously in the 


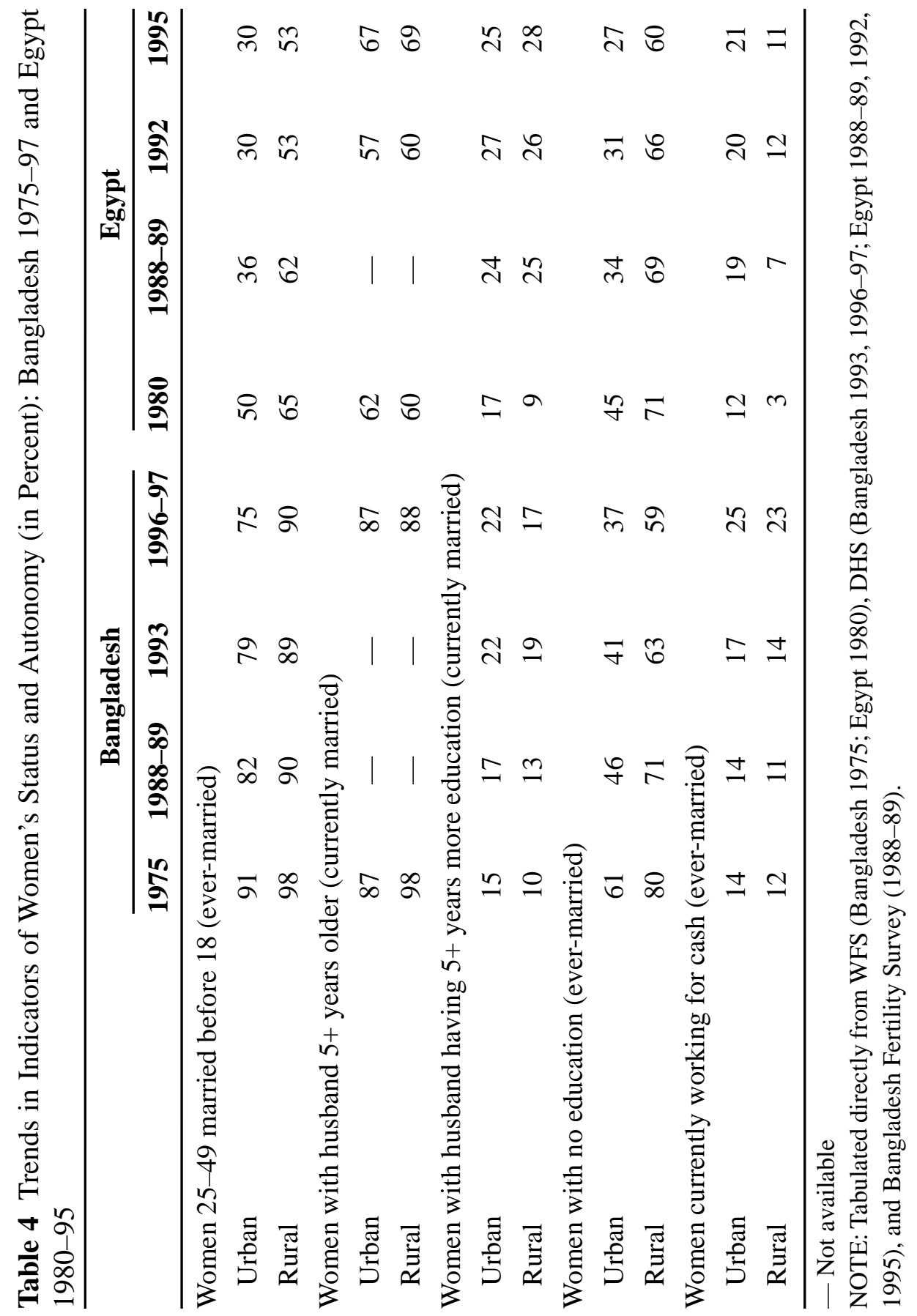


past, when few men or women attended school, the possibility for such differentials was limited.

Despite all the above similarities, a fundamental and consequential difference in marriage practices is the considerably earlier ages at marriage for women in Bangladesh and the resulting greater age difference between spouses. There is no ready explanation for this pattern except to note that both Bangladesh and Egypt adhere to broad regional patterns. Table 4 shows levels and trends in the percent of women aged 25-49 married before the age of 18 in urban and rural areas. While marriage age has been rising in both countries and in urban and rural settings, the proportion of women marrying before 18 in urban Bangladesh remains a surprising 75 percent, in contrast to 30 percent in urban Egypt. Similar differences between the two countries persist in rural areas, where 90 percent of women in Bangladesh are married before 18 as compared with 53 percent in Egypt.

It is likely that these differences in the average age at marriage are associated with customs and practices related to sexual control of young women. Recent data from Egypt have documented a very high prevalence of female circumcision (97 percent of all ever-married women), most of it involving partial or total excision of the clitoris (El-Zanaty et al. 1996). These practices are nonexistent in Bangladesh. Defloration ceremonies to validate a bride's virginity are common in Egypt, but almost unheard of in Bangladesh. In general, probably because of a tradition of early marriage, practices and rituals to ascertain virginity at marriage or to ensure virginity at the time of marriage are not as developed in Bangladesh as they are in Egypt or other settings where marriage occurs at a later age for women.

A concomitant of early marriage for women is the age difference between spouses. The World Fertility Survey showed that the median age difference between spouses was 6.2 years in Egypt and 9.1 years in Bangladesh (Casterline, 
Williams, and McDonald 1986). Consequently, in 1996-97, 88 percent of women in rural Bangladesh were married to husbands more than five years older, compared to 69 percent in rural Egypt in 1995 (see Table 4). The corresponding figures for urban areas are nearly identical -87 percent in Bangladesh and 67 percent in Egypt. There is some indication from more localized studies that small changes in age differences at marriage have taken place. Amin and Cain (1997) present data from two Bangladeshi villages in the 1990s which suggest that, although age at marriage has risen slightly for women, the consequent change in spousal age differences has been minimal.

Cain's (1984) explanation for differences in gender systems across societies links differences in spousal age to women's vulnerability in marriage and hence to the strength of patriarchy. According to this measure, Bangladeshi society is among the most strongly patriarchal in the world. In order for men to remain married for as long as they do and not spend time in the divorced or widowed state, everything else being equal, large age differences require a greater number of years spent in either the divorced or widowed state for the younger partner. Goldman and Pebley (1989) showed that, in Bangladesh, this is achieved by higher rates of remarriage for men. In Egypt the mean age difference is considerably lower.

In Bangladesh, dowry demands at marriage have become commonplace, although it was not the custom even a generation ago. The rise of dowry in Bangladesh is similar to trends in other South Asian communities where it was not part of the traditional marriage transaction. While a full exploration of the rise of dowry is beyond the scope of this paper, it is clear that the advent of such a practice has strong negative implications for women (Amin and Cain 1997). It reinforces preference for sons and has immediate implications for the young daughters of a household who cannot be married off until the accumulation of dowry. In Egypt, there are reports of rapid inflation of costs related to marriage that may 
take the form of gifts given or festivities held around the event of marriage (Barakat 1985). While these may be equally burdensome for the families of the bride and the groom in financial terms, the rationale for gifts or marriage festivities in Egypt is to secure a good marriage, standing in sharp contrast to the practice of dowry in Bangladesh, which is more crudely about paying a man to take a daughter off a father's hand. The symbolic import of these cultural practices on the prestige of women is considerable. It is also clear that the inflation of marriage costs imposes significant financial burdens on families in both contexts.

\section{Remunerative Work}

As with marriage law and practice, there are both similarities and differences between Bangladesh and Egypt in the ability of married women to earn cash for their work. The similarity between the two countries lies in the levels of women engaged in remunerative work, which are relatively low by international standards; the differences lie in the type and location of work among the small minority of women who are able to earn cash and in the recent sharp increases in Bangladesh.

The literature contains hugely varying estimates of the level of women's labor force participation in developing countries; this is because of the difficulty of measuring much of the work that takes place outside the modern sector when employment is not formalized, salaries are not paid, and work is irregular and/or seasonal. It is widely recognized that much of the economically valuable work performed by women is never counted (United Nations 1995c), but attempts to rectify the undercount often lead to further confusion as estimated levels of women's labor force participation fluctuate widely from survey to survey. ${ }^{7}$

In order to create some consistency between estimates, we have gone back to the original wording from each of the WFS and DHS surveys on work from Egypt and Bangladesh, and counted only those women who reported currently 
working for pay or cash at the time of the survey. ${ }^{8}$ We focus on work for cash because we feel that only when women are able to earn cash on their own account — rather than indirectly earning cash for the family by contributing to earnings from a family farm or business or providing savings to the family even more indirectly by growing food for home consumption - are they able to gain some control over spending and some decisionmaking power within the home.

Our estimates of work rates suggest that labor force participation is relatively low and that little change occurred during the initial years of fertility decline. This assessment is also supported in the case of Egypt by data on female participation in economic activity from the 1976 and 1986 censuses (Fergany 1994 as cited in Fargues 1997). However, there has been a rather sudden increase in the proportions of women reporting work for cash between the 1993 and the 1996-97 surveys in Bangladesh. The changes in Egypt are very small, and probably trivial (Table 4). The latest surveys show the percent of women working for cash in urban Bangladesh to be slightly higher than in urban Egypt (25 percent versus 21 percent), representing a reversal since Egyptian rates were higher than those for Bangladesh in the previous two surveys. The rural comparisons are somewhat different: Bangladesh always had slightly higher rates compared to Egypt and now the difference is substantial (23 versus 11 percent). ${ }^{9}$ As we discuss later, there is some evidence that the rise of cash work may be related to the experience of NGO activities in rural Bangladesh. The important finding from our point of view is the overall low rates of work for cash by married women prior to, or during the early years of fertility decline in either society.

Differences between Egypt and Bangladesh in gender systems as they relate to women's work manifest themselves largely in work location, a factor that is closely linked to type of activity. Table 5 indicates that, for those married women who work for cash, the majority of women in rural Bangladesh work at home (80 percent) and, even in urban areas, 47 percent work at home. More striking is the 


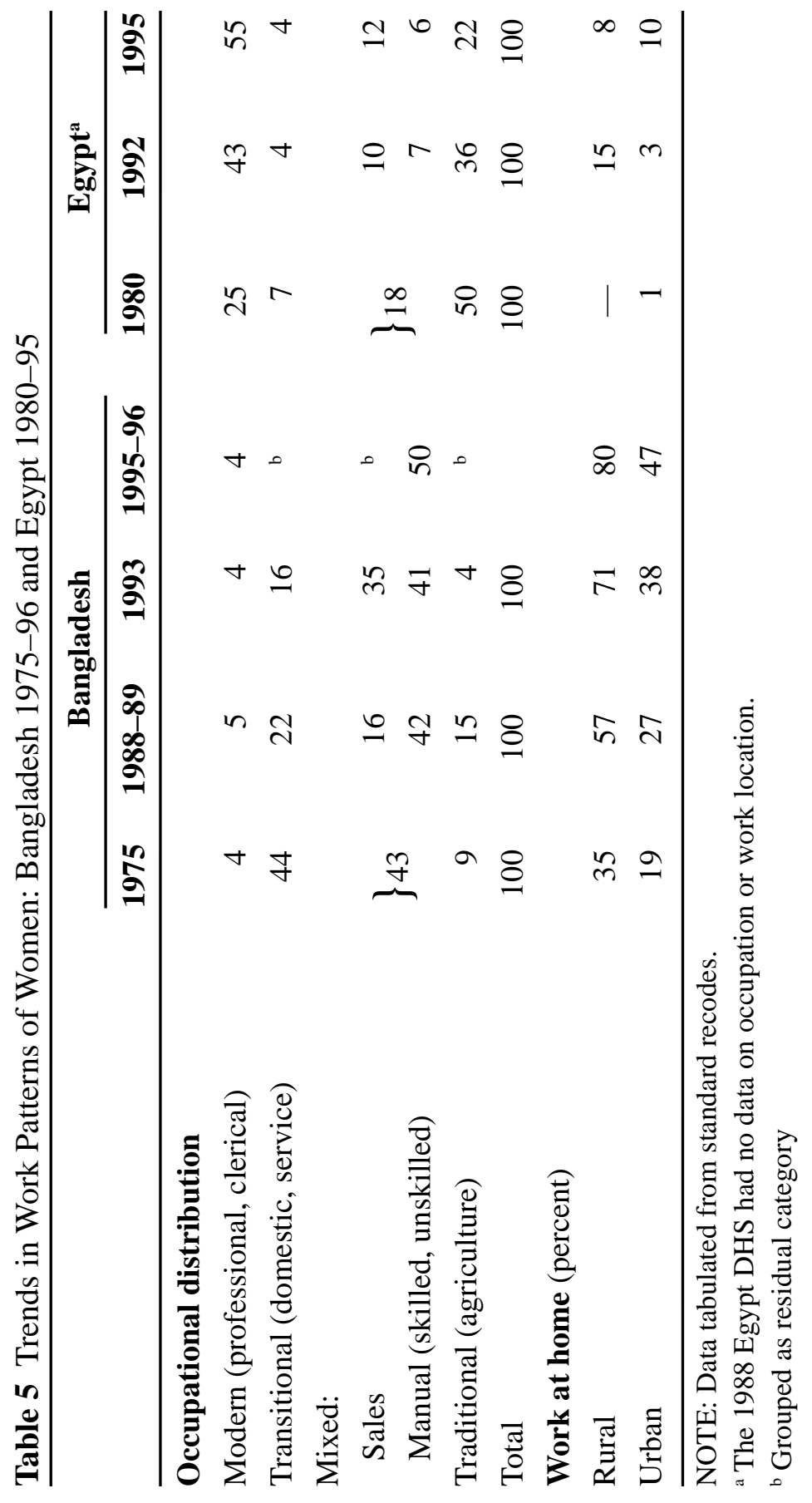


rise in the percent of women's cash work taking place at home. The percentages of all women working for cash at home among those working for cash in 1975 were 35 and 19 in rural and urban areas respectively. This may partially reflect the growth of micro-enterprise and credit schemes for women, which increasingly give them the flexibility of working at home. By contrast, only 8 percent of working women work at home in rural Egypt and only 10 percent in urban Egypt. The occupational distribution for working women is also very different in the two countries. While few working women in Bangladesh work in the modern professional or clerical occupations associated with salaried work, a rising percent of Egypt's working women do so. The proportion of women in salaried jobs has risen from 25 to 55 percent between 1980 and 1995. In contrast, only 4 percent of Bangladeshi women hold professional or clerical jobs. Given that most other forms of work for Bangladeshi women largely take place at home, we presume that this work is more traditional than it might be in another setting. In contrast to Egypt, where almost a quarter of the paid female labor force works outside the home in agriculture, agriculture is not an important source of cash work for women in Bangladesh.

\section{Seclusion}

The practice of seclusion or purdah, usually associated with Islamic societies, has been implicated in women's low levels of labor force participation in Bangladesh. In addition, there is some evidence from West Bengal, where labor force participation among Hindu Bengali women is also considerably limited, that the local culture interacts with Islamic injunctions of female seclusion to reinforce the limits on women's work. The study of purdah and its evolution in Bangladesh has a long history, and there is now a reasonable consensus that the practice and meaning of purdah continue to evolve with changing social circum-

stances. For instance, Simmons, Mita, and Koenig (1992) demonstrate how, among 
female family planning workers whose primary responsibility is to go door-todoor to offer services and encourage birth planning, women reinterpreted purdah to mean modesty in thought, rather than modesty in dress as it is commonly understood. Similarly, Siddiqi (1991) argues that garment-factory workers who have to work alongside men have chosen to focus on the indoor-outdoor space definition related to women's seclusion, and the factory floor is depicted as secluded space like the home, where there is strict supervision and therefore control to prevent illicit contact between the men and women who work there. The experience of the first generation of working women, where work is considered a major violation of the norms of seclusion, suggests that while women reinterpret the meaning of specific purdah practices to suit the circumstances of their own work, few challenge the basic tenets of the custom of seclusion, or its objective, which is to control the women's sexuality.

In Egypt, it is evident from the mobility data shown in Table 2 that the practice of seclusion operates differently. While overall levels of participation in the labor force remain low, women are freer to move outside the home. In particular, it is acceptable for women to trade in the market and to congregate for prayers in mosques - freedoms that Bangladeshi women traditionally do not enjoy. Perhaps because of this greater degree of participation by women in some public institutions, Egyptian women report greater mobility than women in Bangladesh.

The practice of veiling has strong symbolic import in both contexts. In Bangladesh, as in most of the Indian subcontinent, women have remained traditional in dress and have never embraced Western clothing even though it is common for men. In contrast, Egyptian women commonly wear European clothes and have done so for some time in urban areas. However, rising anti-Western sentiments and religious revivals have brought back the veil in several quarters. It is probably also relevant that historically in Bengal, the central cultural issue of 
women's seclusion was about spatial confinement in the home-thus, the word zenana (indoor space, women's world) appears frequently to refer to the practice of seclusion rather than to other concepts related to purdah.

In Bangladesh, specifics about women's dress codes have never been as contentious as they appear to be in Egypt. Part of the explanation may be that dress codes have remained traditional in other ways and never changed as dramatically as they did in Egypt. But the more important underlying explanation must be that women do not appear in as many public places as women in Egyptveiling only emerges as an issue to regulate or circumscribe the presence of significant numbers of women in the public arena.

\section{THE ROLE OF THE STATE}

In myriad direct and indirect ways, the actions and reactions of the state have a bearing on the social and economic context within which individuals and couples develop and implement their reproductive decisions. State policy-in both its active and passive forms - also plays a role in the evolution of gender systems, through its direct implications for the evolution of economic opportunities for women as well as indirectly as a consequence of policies or state actions designed for other ends (McNicoll 1998). In this section we review some of the key ways over the past 20 years that the governments of Bangladesh and Egypt have shaped women's lives and the opportunities they face, with potential implications for the pace of fertility decline, not only directly through their population policies but also indirectly through their very different development styles and social policies.

Although both Bangladesh and Egypt took their cues on policy formulation from international trends in development fueled substantially by aid flows, their rural development policies have differed considerably. Bangladesh has taken

a more proactive role in targeting women and the rural poor than Egypt, probably 
as a response to its widely held image as the international "basket-case" at the time of its independence in 1971.

At about the same time as Bangladeshi independence, Egypt experienced an economic and political turning point in 1973 because of Anwar Sadat's infitah, or open door economic policies, but the spirit of the policies could not have been more different from those being formulated in Bangladesh. Rising out of the peace agreement with Israel, the open door policies were related to a more traditional development approach. Egypt has fared far better than Bangladesh in terms of growth in per capita income, consumption, improved life expectancy, and other aggregate quality-of-life indicators. As discussed above, however, these improvements in levels of living have been accompanied by high and rising inequality within the society.

We begin with a short review of population policy in the two countries, with a focus on differences in family planning service delivery, and then treat in greater depth three aspects of the role of the state that are particularly salient to the issues at hand: the role of NGOs as partners in rural development, the state's investment in education for girls, and the state's reaction to rising religious fundamentalism.

\section{Population Policy and Family Planning Services}

Bangladesh and Egypt have similar early histories of population policy. In both settings, concerns about rapid population growth and high population density were evident more than 50 years ago. The first discussions about population growth and the need for control were sounded in Egypt as early as 1937 (Ibrahim and Ibrahim 1998). In the area of present-day Bangladesh, as well as in India, similar concerns about population pressure were voiced in the 1930s and 1940s (Srinivasan 1995). Early policy initiatives in the two countries appear to have been similar in the 1960s, with considerable emphasis on promoting small-fam- 
ily norms but little investment in infrastructures for service provision. Several recent studies provide comprehensive reviews of population policy (Robinson and El-Zanaty forthcoming on Egypt; Cleland et al. 1994 on Bangladesh). In this section, we provide a discussion of the main points.

In Bangladesh, a major turning point in the population sector came in the mid-1970s with strong high-level pronouncements about commitment to population and, more importantly, a decision to employ a large cadre of family planning workers to offer doorstep delivery of services. Female paramedics visited women in their homes and offered contraceptive methods and limited health services. The doorstep-delivery model was widely recognized as a highly successful means of service provision in rural Bangladesh, and the reliance on female paramedics increased. Starting in the late 1970s, menstrual regulation services were provided by a slightly more highly qualified cadre of paramedical personnel. In 1995 more than 5,000 Family Welfare Volunteers, trained to provide menstrual regulation services, insert IUDs, and administer injectable contraception, were posted in rural health centers throughout the country. These paramedics are also trained to provide basic antenatal services and to immunize women and children against major childhood diseases.

In Egypt, while there has been a steady rise in government attention to population issues over the years, only in 1984 did the government adopt clear policy objectives for the population sector, and in 1993 the former National Population Council was elevated to Ministry status (Ibrahim and Ibrahim 1998). While the government's population policy involves much more than family planning, its main thrust has been the distribution of contraceptives in family planning clinics. There has always been a heavy reliance on trained medical personnel for the provision of family planning services in Egypt.

A comparison of the distribution of contraceptive use by method between Bangladesh and Egypt reflects this medicalization (see Figures 3A and 3B). Egypt 
Figure 3A Trends in Contraceptive Method Mix: Rural Bangladesh 1975-97 and Rural Egypt 1980-95 (Percent of Currently Married Women)

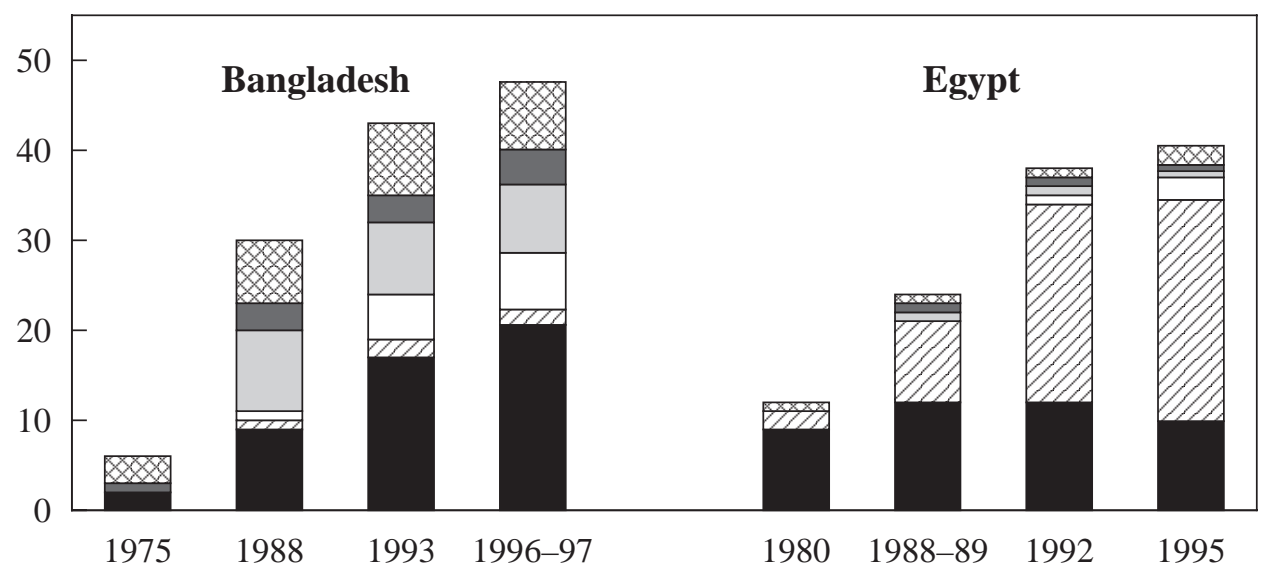

Figure 3B Trends in Contraceptive Method Mix: Urban Bangladesh 1975-97 and Urban Egypt 1980-95 (Percent of Currently Married Women)

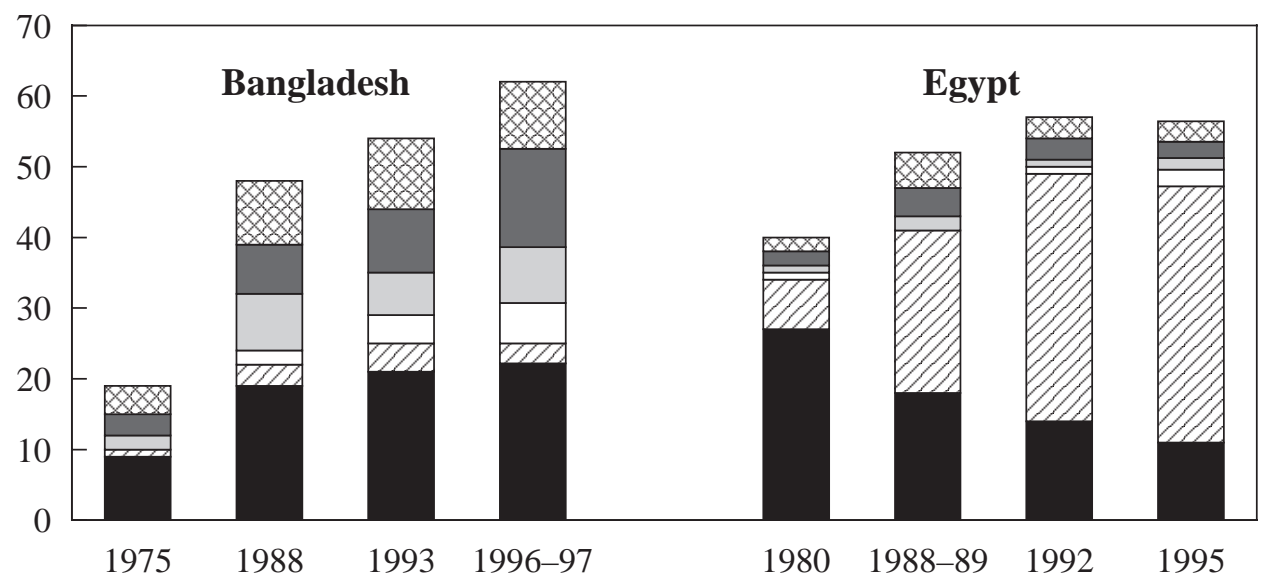

Other $\square$ Female Sterilization $\square$ IUD

$\square$ Modern Male $\square$ Injections $\square$ Pill 
and Bangladesh have similar levels of overall contraceptive use but considerably different method mixes. In general, there is a greater variety of contraception in use in Bangladesh, whereas in Egypt the majority of women rely on the IUD. The use of male methods and condoms is also slightly higher in Bangladesh, where the most popular method appears to be the pill. The greater use of pills and condoms may be attributed to the reliance on family planning workers, for whom these are the easiest methods to promote in contrast to methods that are more appropriately provided in clinic settings.

The family planning program in Bangladesh is characterized by a service delivery structure that is demedicalized and relies instead on a team of female paramedics. The program expanded steadily through the 1970s and 1980s, and by 1990 there were 2,354 rural family welfare centers and 24,000 female paramedics (Cleland et al. 1994). Simmons, Mita, and Koenig (1992) make a strong case that family planning workers are important role models for young women, as they were the first generation of women in rural Bangladesh with formal employment. It is also significant that most of the workers are recruited from the area in which they serve. In contrast, Egypt relies much more on doctors who are dispatched to rural clinics, where women are expected to travel to obtain services. Although there are 3,700 government family planning service outlets, the majority of women (63 percent) report using private-sector services. As a result, services are physically as well as psychologically less accessible in Egypt than in Bangladesh.

\section{Rural Development and the Role of NGOs}

The approaches to rural development in Bangladesh and Egypt differ markedly in terms of the role played by nongovernmental organizations. Beginning in the 1970s, NGOs have played an increasingly important role in rural development in Bangladesh, whereas in Egypt their activities are small scale, highly localized, and barely visible. The historical context in which these organizations 
came into being may be relevant. In Bangladesh, the first development NGOs were established after the war of independence in 1971. These organizations began initially with relief work to rehabilitate dislocated families. After the first phase of rehabilitation, NGOs found themselves increasingly involved in longerterm poverty alleviation activities for which substantial amounts of donor assistance continued to be available. The focus remained on the most vulnerable components of the population: women and children. During the 25 years since independence, NGOs evolved to provide services in the credit, education, and health sectors. An important common element of the style of development practiced by NGOs is their reliance on outreach services, some of which were set in place during times of famine and other natural disasters. For instance, even now a high level of development activities remains in the districts hardest hit during the famine of 1974.

The four largest organizations in Bangladesh are best known for providing credit to rural women: BRAC (Bangladesh Rural Advancement Committee), Grameen Bank, ASA (Association for Social Advancement), and Proshika. Together, they have outstanding loans to 3.1 million beneficiaries, most of whom are women (Centre for Policy Dialogue 1995). According to the 1996 Demographic and Health Survey, while 7 percent of women are members of Grameen, 70 percent of all respondents lived in a village where at least one other respondent was a member. The parallel figures for BRAC are 8 percent and 25 percent. Half of all women are not eligible because they are judged to be non-poor based on size of landholding and other criteria. Beneficiaries of these programs are usually poor rural women who receive collateral-free credit.

While numerous NGOs are active in Egypt, the scale of operations for most is much smaller than in Bangladesh. Similarly, there are small-scale efforts to provide credit to women. Many of the NGOs have replicated programs such as Grameen and BRAC, but none exists on the same scale as in Bangladesh. 
Although part of the explanation for the growth of NGOs in Bangladesh may be attributed to the post-independence needs of reconstruction and rehabilitation, the relatively liberal regulatory environment also encouraged the rapid expansion of the nongovernmental sector. NGOs in Bangladesh have considerable autonomy and are only loosely regulated in their receipt of foreign donations. In contrast, the regulatory environment in Egypt is much more restrictive. It has been suggested that specific provisions in the relevant organizational laws, such as a requirement that a senior member of the government should serve on the board of every organization (Law 32 adopted in 1964), have inhibited the growth of the nongovernmental sector in Egypt (Kandil 1995).

The mode of operation of NGOs undoubtedly represents an important contribution to the process of social change. Unlike governmental services or the private sector, the approach of NGOs is to involve communities and to offer services at the community level. This is achieved through a widespread network of rural centers and an emphasis on outreach services. For example, BRAC runs schools in rooms donated by the local community, usually in someone's home. Grameen, BRAC, and ASA hold meetings in sheds or rooms constructed in the homes of one of their members. Meetings are convened by a bank officer who travels to the rooms where women meet. This approach of service delivery, it may be argued, makes for a radically different environment for social interaction than one in which services are available in urban centers or marketplaces that are not equally accessible to all, particularly not to women.

A recent panel study of the rise in contraceptive acceptance after the introduction of a credit program suggests that while program members already differ from nonmembers to start out, the introduction of micro-credit in a village leads to considerable increase in contraceptive use within a short time, suggesting that micro-credit may contribute to a village environment that is more open to innovative behavior (Steele, Amin, and Naved 1998). Thus, although the onset of 
fertility decline preceded NGO expansion in Bangladesh, the expansion of NGO activities may nevertheless explain the rapid pace of contraceptive acceptance.

Contrary to the assertions made in recent articles about the family planning program in Bangladesh (Schuler et al. 1996; Schuler, Hashemi, and Jenkins 1995), there is probably not much difference in the approaches taken by credit extension services and by the government family planning program. Both have innovated strategies to overcome women's lack of access to services and their low mobility. NGOs employ large cadres of extension workers who spend the better part of the day traveling to women's compounds to conduct credit transactions or offer education, in much the same way as the family planning providers who call on women of reproductive age to offer them contraceptive methods. Women who are served by these programs remain reluctant to travel large distances but are willing to use the services if they are brought to them. While doorstep delivery may enable women to remain in purdah, it may also be seen as empowering women. Thus, by entering the homestead compound and giving women greater access, providers of these services are expanding women's traditional power and authority within the domestic sphere.

Indeed, in a recent statistical analysis of the effect of women's cumulative exposure to the visits of family welfare assistants in Bangladesh, Phillips and Hossain (1998) found that various measures of women's status have improved. This can be partially explained by the effect of outreach on fertility and the improved status that is associated with birth planning.

Egypt's rural development approach is far more traditional and focuses primarily on men. The government bureaucracy plays a considerable role, and nongovernmental organizations a very limited one. Investments in modernizing agricultural technology have been the key. These have been accompanied by investments in transportation networks and rural electrification. The pivotal role of state bureaucracies is reflected in the attention given to them in studies of the 
rural political economy in Egypt (see Hopkins 1987; Adams 1986; Richards 1982). These studies are also remarkable for their lack of attention to gender issues.

In terms of such issues, Egypt has invested in affirmative action programs in the public sector to give preferential treatment to women. As a result, most women who work in Egypt are engaged in public-sector employment. These policies have created opportunities for women to leave home for work, thus influencing fertility through the more traditional routes of increasing the opportunity costs of women's time. By contrast, the recent upswing in the proportion of women in Bangladesh working for cash at home is most likely attributable to the credit programs run by various large NGOs.

\section{Education for Girls}

Both Egypt and Bangladesh have seen gradually rising school enrollment over the past three decades, with a more rapid increase among the youngest cohorts. These changes in educational attainment for girls have been associated with specific policy decisions. The low levels of education among adult women surveyed support the view that rising enrollment is a relatively new phenomenon.

Proportions of ever-married women who have never been to school in rural areas remain high in both countries despite some decline. Table 4 shows that 80 percent of ever-married women in rural Bangladesh and 71 percent of evermarried women in rural Egypt reported no education in the World Fertility Surveys conducted in 1975 and 1980 respectively. In Bangladesh the percentage of women with no education in rural areas fell to 71 percent by 1988-89 and to 59 percent by 1996-97. The data suggest that the extent of illiteracy of reproductive-aged women, as measured by proportions who never went to school, is currently about the same in the rural areas of the two countries (about 60 percent), and is some 10 percentage points higher in Bangladesh than in Egypt for urban 
areas. Taking another measure of schooling - the proportion of women with at least four years of education-we also see surprising similarity between rural Bangladesh and Egypt, with only about a third of women having gone that far in school (see Table 2).

Examining trends in educational attainment, we see some recent improvements in the situation of girls that we expect will have positive implications for gender systems in both countries. Figure 2 compares proportions by age group who have completed grade four in both settings. Overall levels of attainment are much higher for boys in Egypt than in Bangladesh, reflecting Egypt's higher level of socioeconomic development. Girls in urban areas also have shown higher levels of attainment in Egypt than Bangladesh. Up until the more recent periods shown, however, girls in rural Egypt and rural Bangladesh have fared equally poorly. The rise in enrollment in recent cohorts is more pronounced for girls in Egypt than in Bangladesh. However, because enrollment for boys has remained static in Bangladesh while it has increased for both sexes in Egypt, the gender gap has narrowed more rapidly in Bangladesh, despite evidence of some narrowing of the gender gap for both countries. This suggests that recent development strategies in Bangladesh that have focused on the poor and disadvantaged, in particular on girls, have paid off and will have long-term implications for women's status. Nevertheless, overall levels of school attainment in Bangladesh are still very low, reflecting higher levels of poverty and greater parental needs for child labor.

In Bangladesh, three large-scale government interventions can be identified as directly affecting girls' enrollment and reducing gender differentials. First, in addition to free primary education for all, secondary school education was made free for girls in the mid-1980s while boys continued to pay fees, resulting in the first reduction of the gender gap. Second, in 1994 two further interventions provided added subsidies and incentives to education, but only in rural areas. These were a food-for-education program for poor primary school children and a 
secondary school scholarship scheme for girls (Amin and Sedgh 1998). Furthermore, beginning in the 1980s, NGO initiatives to encourage nonformal education probably helped to boost young-age enrollment. The scale of these programs is large enough to affect national enrollment rates in a manner not usually expected of private initiatives. The largest program is run by BRAC, which in 1996 was operating some 35,000 schools with 30 students each, providing up to three years of education. With only 56,000 public primary schools in place, it is clear that BRAC schools play a considerable role in providing education to the youngest age groups.

Well before the adoption of the Egyptian Constitution in 1971, the government was committed to providing free basic education to all Egyptian children in state-run institutions. In 1981, compulsory schooling in Egypt was extended from six to nine years but never fully enforced (Shafey 1998). In the face of economic difficulties in the mid-1980s and to fulfill the cost recovery requirements of structural adjustment, the Ministry of Education was forced to institute modest school fees (Fergany, Farmaz, and Wissa 1997), and in 1988 the duration of basic schooling was reduced from nine to eight years. A marked increase in political commitment to education has occurred in the 1990s. President Mubarak declared education the national project for the decade, and major education reforms were instituted in 1991 focusing primarily on infrastructure (Shafey 1998). The introduction of alternative schools in underserved areas, such as one-room schools and community schools in collaboration with UNICEF, represents new approaches particularly focused on the underenrollment of girls. While enrollments have been rising in response to these initiatives, there is also evidence of declines in quality of schooling since the late 1980s resulting from overcrowding and doubleshifting (Shafey 1998).

Improvements in educational access as well as greater gender equality in educational opportunities can have implications for aspects of the gender system 
we have discussed thus far-namely, marriage, work, and seclusion—as well as for fertility more directly. Greater participation in school and more years of education for girls tend to delay marriage and may even have implications for marriage costs if educated brides are more highly valued. More schooling for girls is also associated with greater workforce participation upon completion of schooling, whether before marriage or after. It is also associated with differences in the practice of purdah, with considerable long-term implications for women's status and the gender system itself. Rising levels of education in the community can also have more immediate effects even on illiterate women, who can experience the wider world through the lives of their school-going daughters. Finally, education raises the costs associated with rearing children and thus motivates parents to have lower fertility.

\section{Government Response to Rising Religious Fundamentalism}

The overwhelming majority of the population in both Egypt and Bangladesh is Muslim (see Table 1). For many years, the stated opposition of Islamic clerics to reproductive freedoms for women was widely felt to be an impediment to fertility decline. This view was given empirical credence by somewhat dated evidence of delayed onset of fertility decline in Muslim-majority settings, all of which have since experienced rapid change in fertility and mortality. It is important to note that, while there is evidence of rising religious extremism in both Egypt and Bangladesh, these movements occurred during the course of rapid fertility declines in both countries.

A recent analysis by Obermeyer (1995) points to the importance of the politics of religious movements rather than to religious doctrine per se as a potential factor in the pace of fertility decline. The contrast between Egypt and Bangladesh lends support to this view and highlights the role of the state in modifying or conditioning the impact of religious extremism. The rising influence of 
Pan-Islamic movements in the 1970s, such as the Jamaat-e-Islami, was evident in both countries. These movements appeared to exert considerable influence within organized political parties and also exerted some influence on social development activities. The political activities of the most extremist parties in Egypt have been either banned or severely circumscribed (Terterov 1996); in Bangladesh the activities of specific Islamic political parties were curtailed in the initial years of independence, but these parties are now allowed to participate in national elections. In Bangladesh, despite their highly sophisticated organizational structure and probably because of the relatively tolerant attitude of the government, the extremists have little popular support. The lack of support for religious political parties in Bangladesh was demonstrated in the most recent parliamentary elections: the religious parties contested all 300 seats but secured only three seats in the Parliament.

Some analysts have attributed the declining influence of Islamic groups in Bangladesh to the increasing participation of women in elections. In the 1996 elections, voter turnout was higher for women than for men (Rahman 1996). Women's participation is promoted by mass voter education campaigns, organized by the government, NGOs, and civil society, that emphasize the importance of participation and the right of each individual to vote according to her own preference. Polling officers also accommodate women's need for maintaining purdah by setting up separate voting booths for men and women.

Since elections are few and far between in Egypt, there is no direct basis for comparison. Several commentators have suggested that the banned Islamic groups have acquired a significant popular following. The repressive stance of various Egyptian governments, which at times have resorted to large-scale imprisonment of the followers of certain political groups, coupled with the considerable role these groups have played in providing health and education services to the poor, may have contributed to the popular support for extremists. Ismail 
(1998) attributes the increasing popularity of the Islamist movement to the diminishing welfare role of the state in Egypt.

It is likely that the significance of religious trends for fertility lies in the extent to which they influence the nature of social interaction. In Bangladesh, the relatively tolerant state response to rising extremism has probably made it irrelevant for demographic trends. However, the Bangladesh government has not faced the same challenges as the Egyptian government. President Sadat's assassination accentuated the tensions within Egyptian society and hardened the government stance against religious extremists. Repressive state responses in Egypt may have contributed to creating a more hostile environment for positive social change in general as well as for fertility change in particular, especially among the poor and disadvantaged groups. The Egyptian government now faces difficult choices. For example, while the recent government ban of veiling in Egyptian schools might be seen as a feminist act by some, in the current political environment it can be alternatively interpreted as insensitive, anti-religious, and undemocratic.

\section{Implications of State Policy for Fertility Change}

What, then, explains the relatively rapid fertility decline in Bangladesh? Bangladesh has followed a somewhat distinct pattern of development, with considerable emphasis on reaching the rural poor and women and a strong reliance on nongovernmental institutions, that may have played a part in bringing about more rapid social change (including fertility change) despite low levels of development. We conjecture that the objectives of targeting underserved segments of the population, and the means of attaining that objective through a heavy reliance on outreach, may have played an important role in fertility decline. The deployment of large cadres of fieldworkers in health, family planning, and rural credit services has direct implications for the opportunities available to women. ${ }^{10}$ The changes brought about by these services are evident in the proportions of women 
who are using contraception and who are within easy access of contraceptives, health services, and credit. An important indirect byproduct of these new and large networks of workers may have been the changes brought about in the social networks through which women encounter and evaluate new ideas and information that affect their notions about ideal family size and motivation to control fertility (Casterline 1998). Other small changes in social and political life may also play a part in creating a society that takes to innovation easily. Some recent changes in election practices have resulted in high voter turnouts especially among women; and the increasing value placed on social consensus and democratic processes may be responsible for more tolerant attitudes toward extremist tendencies, whether in religious fundamentalism or in women's movements, that help to defuse the extreme elements in these movements.

An entirely different causal mechanism appears to lie behind trends in fertility in Egypt. Given the remarkable rise in overall income, consumption, and education during a time of declining fertility, a case can easily be made to fit Egypt into a more traditional demographic transition model that relates fertility to steadily improving standards of living. ${ }^{11}$ Another factor driving the Egyptian trends is the high level of urbanization and the attendant influences of urban life on both urban and rural fertility aspirations.

A critical distinction between the experiences of Bangladesh and Egypt is the extent of women's participation in the process of change and the implications of these experiences for women's lives in the future, in the context of smaller families.

\section{CONCLUSION}

Since the early 1980s, Bangladesh and Egypt have experienced similarly rapid fertility declines. The similarity in trends is most clearly demonstrated when data are disaggregated for rural and urban women. Contraceptive levels are now 
similar in both rural and urban areas, and, given the later ages at marriage and higher levels of development in Egypt, Bangladesh appears to have achieved unexpectedly low levels of fertility during the 1990s when the pace of the decline accelerated. The longer duration of breastfeeding in Bangladesh only partially compensates for the much earlier ages at marriage in that country. Therefore, lower-than-expected levels of fertility in Bangladesh must be explained by lower levels of desired fertility, the greater availability of abortion and contraceptive services that have resulted in a more varied method mix, and the more effective and efficient use of contraception in Bangladesh relative to Egypt.

During this period of rapid fertility decline in Egypt and Bangladesh, there is little evidence of change in the standard measures of women's status and autonomy that are usually associated with lower fertility. While women's educational levels have improved slowly, evidence of rapid change in enrollment rates of children and a reduction in the gender gap in education in both countries have appeared only recently. Egypt has higher levels of overall educational attainment but also a larger gender gap in schooling than Bangladesh. In general, changes in education in both countries appear to have occurred well after the fertility decline was underway.

Some of the resistance to greater autonomy for women may be attributed to rising religious extremism in both settings during the 1980s. However, the politics of religious extremism were experienced differently in the two countries and it is likely that the influence of extremism was not as harsh in Bangladesh as in Egypt. The two settings also differed significantly in their styles of development. Egypt followed a more traditional approach of infrastructural development, whereas Bangladesh followed an approach focused on poverty alleviation that targeted resources and services to the poor and to women. The difference in approach was probably most pronounced in the areas of family planning services and availability of rural credit services. In Bangladesh, development programs 
concentrated on addressing barriers to women's access to services. The design of service delivery in all sectors in Egypt has been based on the assumption that clients will seek out the services.

Social trends, the political climate, and the strategy of development may have resulted in an environment in Bangladesh that is more open to innovation and change. Furthermore, the approach to development typified by the Bangladesh experience may provide more opportunities for women, particularly poor women. Rather than directly promoting the labor force participation of women, greater emphasis has been placed on reducing barriers to women's access to resources. This approach to development does not challenge the corporate nature of the family and household by promoting autonomous behavior, but rather enables women, through access to family planning and health resources as well as credit, to expand and strengthen their traditional spheres of influence within the family. While accommodating women's traditional roles within the family that center on care and nurturing, this strategy expands women's influence by giving them direct access to services, information, and cash.

This comparison between Bangladesh and Egypt leads us to two final observations. First, low levels of women's autonomy have been no barrier to fertility decline in either country. Second, the process of fertility decline can bring with it the seeds of change for gender relations, as women gain greater control over their fertility in a way that meets their reproductive health needs and the needs of their families. Some evidence of this exists in the recent upsurge of women working for cash in Bangladesh. Despite greater poverty for women in Bangladesh, it appears that a service and NGO environment that expands women's access to and control of resources within the home and puts them in touch with women from outside their immediate social network-a domain of traditional status and influence for women-has resulted in stronger motivation to limit fertility. In Egypt, where the causal mechanism for change operates in the public 
domain, with greater potential for causing conflict within the private domain of the family, the motivations to limit family size appear to be weaker. While we expect that fertility decline will eventually expand opportunities for women in both Bangladesh and Egypt, the evidence indicates that women in Bangladesh, despite their greater poverty, have become more immediate beneficiaries of that process.

One lesson that emerges from these two case studies is that even though changes in gender relations are not the trigger for fertility transition, population and development policies can have strong intended and unintended gender dimensions. Nevertheless, where women's needs must be served but their lives remain severely constrained, policymakers face difficult choices. Is it better for policymakers to accept those constraints and try to broaden women's opportunities by bringing services to them, or is it better to create opportunities for women outside their traditional sphere that require them to challenge the power structures in order to take up those opportunities?

While this question has been debated in countries like Bangladesh for some time, ${ }^{12}$ our analysis can provide some insight. Without ignoring the extreme poverty and constraints that continue to face women in that society, we have shown that considerable change in the control of reproduction, in the education of girls, and, more recently, in women's access to income have come about with incremental changes in women's opportunities rather than revolutionary changes in underlying gender relations. It remains uncertain, however, whether the expansion of opportunities that Bangladeshi women have experienced within the home will ultimately be "empowering" for women in the ways intended by the language of the Cairo Programme of Action. What is clear, nonetheless, is the enormous difficulties girls and women face in taking up new roles when they lack social support or public assistance. Given the enormous distance societies need to travel to achieve the ambitious goals of the Cairo agenda, policies need to 
focus not just on the creation of opportunities for women but, as importantly, on the provision of social supports that allow women to take advantage of those opportunities. It is particularly in this area that the NGO sector can play a crucial role.

\section{Notes}

The authors gratefully acknowledge comments from John Bongaarts, Judith Bruce, John Casterline, Adrienne Germain, Donald Heisel, Barbara Ibrahim, Carolyn Makinson, and Gita Sen in the preparation of this paper.

1 Regression estimates associating contraceptive use with total fertility suggest that a 10 percentage point difference in contraceptive use is required to predict a fertility difference of 0.7 births (Mauldin and Segal 1988).

2 Another proximate determinant that can contribute to fertility is the duration of amenorrhea associated with breastfeeding. Table 1 shows that mean duration of amenorrhea after birth is somewhat greater in Bangladesh because of longer durations of breastfeeding.

3 See Casterline (1998), Mason (1997a), and Bongaarts and Watkins (1996) for recent references; for earlier descriptions see Coale (1973), Kreager (1991), and Lesthaeghe (1980).

4 These factors are the percentage of people expected to die before the age of 40, the percent of adults who are illiterate, and a composite measure of standard of living, including the percentage of people with access to health services and safe water and the percentage of malnourished children under age five.

5 While levels of poverty are considerable in both countries, in Bangladesh there is some consensus that improvements are evident (Sobhan 1995). Discussions 
among policymakers in Egypt reflect continued concern about regional disparities, notwithstanding a recent IFPRI study challenging past measures of regional differences (El-Laithy 1998; Datt, Jolliffe, and Sharma 1997).

6 The figure for Egypt is based on the calculation that only 6 percent of the land mass is inhabited, whereas the figure for Bangladesh is based on the assumption that 100 percent is occupied (Egypt DHS 1995; Bangladesh DHS 1996).

7 For example, in Bangladesh estimates of female labor force participation rates rose from 8 percent in 1984-85 to 62 percent in 1989 as a result of the broadening of the definition of work from one labor force survey to the next to include previously excluded categories such as threshing/cleaning, husking/drying/boiling, processing and preservation of food, poultry care and raising, and livestock care and raising (Rahman 1996). Trends implied by such changes in definition are clearly implausible.

8 Nowhere in any of these surveys is the reference period clearly specified. Does the question posed imply work in the last week, month, or season? It seems to have been left up to the respondent to interpret. Fortunately, the narrower the definition of work, the less sensitive the measure is to variations in the reference period or minimum work-time requirement (Anker 1990). Indeed, it appears that, in countries like Bangladesh and Egypt, where few women work for cash after marriage, the proportion of women who have ever worked after marriage and the proportion of women who are currently working are remarkably similar (United Nations 1985). This suggests that the small minority of women who work are consistent in their pattern of work and very different from the majority of other women who never work. 
9 Our estimates for rural Egypt are slightly lower than estimates made in a special methodological survey conducted by CAPMAS in rural Egypt in 1983 to refine the measurement of labor force concepts; in that survey the paid labor force participation rate for women varied between 11 and 15 percent depending on the reference period but included "in kind" work, which was not included in our definition (Anker 1990). On the other hand, our estimates for Bangladesh appear slightly higher than the overall rate of 8 percent estimated by Rahman (1993) for 1984-85. Given the problems associated with estimating women's work in low-income countries, even when we restrict ourselves to cash work, it is difficult to assign much meaning to small statistical differences.

10 While the large cadres of government family planning and health workers have been in place since the late 1970s, NGO activities in credit and other social services took a discrete jump from relatively low levels in the early 1990s with the rapid expansion of the Grameen, BRAC, and ASA programs (Sobhan 1995).

11 Some farfetched claims have been made to explain fluctuations in crude birth rates that are probably in part explained by shifts in the age structure produced by declining mortality. In particular, Fargues (1997) attributes rising birth rates in the 1970s to the open economy policy, or infitah, resulting in rising wages, remittances from abroad, and a construction boom; this period was followed by an economic downturn in the 1980 s coinciding with a fall in birth rates. The same analysis contains contradictory, but more convincing data relating monotonically rising educational attainment to monotonically declining fertility during the same time period in which crude birth rates appear to fluctuate. 
12 Recently, the Bangladesh family planning program has decided to shift from home delivery to onsite clinic services. An important question is whether women, given their limited mobility, will feel free to travel to clinics for services.

\section{References}

Adams, Richard H., Jr. 1986. Development and Social Change in Rural Egypt. Syracuse: Syracuse University Press.

Agarwal, Bina. 1997. “'Bargaining' and gender relations: Within and beyond the household," Food Consumption and Nutrition Division Discussion Paper No. 27. Washington, DC: International Food Policy Research Institute.

Amin, Sajeda. 1996. "Menstrual regulation in Bangladesh," paper presented at the International Union for the Scientific Study of Population Seminar on Abortion, 25-28 March, Kerala.

- 1997. "The poverty-purdah trap in rural Bangladesh: Implications for women's roles in the family," Development and Change 28, no. 1: 213-233.

Amin, Sajeda and Mead Cain. 1997. "The rise of dowry in Bangladesh," in Gavin W. Jones, Robert M. Douglas, John C. Caldwell, and Rennie M. D’Souza (eds.), The Continuing Demographic Transition. Oxford: Clarendon Press, pp. 290-306.

Amin, Sajeda and Gilda Sedgh. 1998. "Incentive schemes for school attendance in rural Bangladesh," Policy Research Division Working Paper No. 106. New York: Population Council.

Anker, Richard. 1990. "Methodological considerations in measuring women's labor force activity in developing countries: The case of Egypt," Research in Human Capital and Development 6: 27-58.

Arends-Kuenning, Mary. 1997. "The equity and efficiency of doorstep delivery 
of contraceptives in Bangladesh," Policy Research Division Working Paper No. 101. New York: Population Council.

Ashurst, Hazel, Sundat Balkaran, and John B. Casterline. 1984. "Socio-economic differentials in recent fertility,” WFS Comparative Studies No. 42. Voorburg, Netherlands: International Statistical Institute.

Balk, Deborah. 1994. "Individual and community aspects of women's status and fertility in rural Bangladesh," Population Studies 48, no. 1: 21-45.

_. 1997. "Defying gender norms in rural Bangladesh: A social demographic analysis," Population Studies 51, no. 2: 153-172.

Bangladesh, Demographic and Health Surveys. 1993-97. Calverton, MD: Macro International Inc.

Barakat, Halim. 1985. "The Arab family and the challenge of social transformation," in Fernea 1985, pp. 27-48.

Basu, Alaka M. 1992. Culture, the Status of Women and Demographic Behavior, Illustrated with the Case of India. Oxford: Clarendon Press.

Bongaarts, John and Susan Cotts Watkins. 1996. "Social interactions and contemporary fertility transitions," Population and Development Review 22, no. 4: 639-682.

Cain, Mead. 1984. "Women's status and fertility in developing countries: Son preference and economic security," World Bank Staff Working Paper No. 682. Washington, DC: The World Bank.

Cain, Mead, Syeda Rokeya Khanam, and Shamsun Nahar. 1979. "Class, patriarchy, and women's work in Bangladesh," Population and Development Review 5, no. 3: 405-438.

Caldwell, John C. 1982. Theory of Fertility Decline. London: Academic Press.

Casterline, John B. 1998. "The onset and pace of fertility transition: National 
patterns in the second half of the twentieth century," paper presented at the Rockefeller Foundation Conference on the Global Fertility Transition, 1822 May, Bellagio.

Casterline, John B., Lindy Williams, and Peter McDonald. 1986. "The age differences between spouses: Variations among developing countries," Рориlation Studies 40, no. 3: 353-374.

Centre for Policy Dialogue. 1995. Experiences with Economic Reform: A Review of Bangladesh's Development, 1995. Dhaka: University Press.

Cleland, John, James F. Phillips, Sajeda Amin, and G.M. Kamal. 1994. The Determinants of Reproductive Change in Bangladesh: Success in a Challenging Environment. Washington, DC: The World Bank.

Coale, Ansley J. 1973. "The demographic transition reconsidered," in International Population Conference, Liège, 1973, Vol. 1. Liège: IUSSP, pp. 5372.

1988. "A reassessment of fertility trends: Taking account of the Egyptian Fertility Survey," in Awad M. Hallouda, Samir Farid, and Susan H. Cochrane (eds.), Egypt: Demographic Responses to Modernization. Cairo: Central Agency for Public Mobilisation and Statistics, pp. 21-86.

Coale, Ansley J. and Susan Cotts Watkins (eds.). 1986. The Decline of Fertility in Europe. Princeton, NJ: Princeton University Press.

Das Gupta, Monica and D. Narayana. 1997. "Bangladesh's fertility decline from a regional perspective," Genus 53, no. 3-4: 101-128.

Datt, Gaurav, Dean Jolliffe, and Manohar Sharma. 1997. “A profile of poverty in Egypt, 1997," International Food Policy Research Institute draft mimeograph. Washington, DC: IFPRI.

Dharmalingam, A. and S. Philip Morgan. 1996. "Women's work, autonomy, and birth control: Evidence from two south Indian villages," Population Studies 50, no. 2: 187-201. 
Dyson, Tim. 1996. "Birth rate trends in India, Sri Lanka, Bangladesh, and Pakistan: A long, comparative view," paper prepared for the International Union for the Scientific Study of Population Seminar on Comparative Perspectives on the Fertility Transition in South Asia, 17-20 December, Islamabad.

Egypt, Demographic and Health Surveys. 1988-95. Calverton, MD: Macro International Inc.

El-Laithy, Heba. 1998. "Poverty measures in Egypt," paper presented at the International Conference on Poverty: Emerging Challenges, 9-11 February, Dhaka.

El-Zanaty, Fatma H. et al. 1993. Egypt Demographic and Health Survey, 1992. Calverton, MD: National Population Council of Egypt and Macro International.

El-Zanaty, Fatma H. et al. 1996. Egypt Demographic and Health Survey, 1995. Calverton, MD: National Population Council of Egypt and Macro International.

Fargues, Philippe. 1997. "State policies and the birth rate in Egypt: From socialism to liberalism," Population and Development Review 23, no. 1: 115138.

Fergany, Nader. 1994. "On the age pattern of the participation of women in economic activity in Egypt," Al-Mishkat Research Notes 4.

Fergany, Nader, Ilham Farmaz, and Christiane Wissa. 1997. "Enrollment in primary education and cognitive achievements in Egypt: Change and determinants," IPR Working Paper Series. Washington, DC: Institute for Policy Reform.

Fernea, Elizabeth Warnock. 1985. Women and the Family in the Middle East: New Voices of Change. Austin: University of Texas Press.

Folbre, Nancy. 1983. "Of patriarchy born: The political economy of fertility decisions," Feminist Studies 9: 261-284. 
. 1996. "Engendering economics: New perspectives on women, work, and demographic change," in The International Bank for Reconstruction and Development/World Bank, Annual World Bank Conference on Development Economics, 1995. Washington, DC: The World Bank, pp. 127153.

1997. "Gender coalitions: Extrafamily influences on intrafamily inequality," in Lawrence Haddad, John Hoddinott, and Harold Alderman (eds.), Intrahousehold Resource Allocation in Developing Countries: Models, Methods, and Policy. Baltimore: Johns Hopkins University Press, pp. 263274.

Goldman, Noreen and Anne R. Pebley. 1989. "Demography of the marriage market in sub-Saharan Africa and south Asia," in International Population Conference, New Delhi, 1989, Volume 3. Liège: IUSSP, pp. 175-188.

Govindasamy, Pavalavalli and Anju Malhotra. 1996. "Women's position and family planning in Egypt," Studies in Family Planning 27, no. 6: 328-340.

Hopkins, Nicholas S. 1987. Agrarian Transformation in Egypt. Boulder and London: Westview Press.

Huq, Najmul and John Cleland. 1990. Bangladesh Fertility Survey: Main Report. Dhaka: National Institute for Population Research and Training.

Ibrahim, Saad Eddin and Barbara Lethem Ibrahim. 1998. "Egypt's population policy: The long march of state and civil society," in Anrudh Jain (ed.), Do Population Policies Matter? Fertility and Politics in Egypt, India, Kenya, and Mexico. New York: Population Council, pp. 19-52.

Ismail, Nagah. 1998. State Development Policies and the Response of the Islamic Movement in Egypt. Dissertation for M.Sc. in Development Studies, School of Oriental and African Studies, University of London.

Jejeebhoy, Shireen J. 1995. Women's Education, Autonomy, and Reproductive Behaviour: Experience from Developing Countries. Oxford: Clarendon Press. 
Kandil, Amani. 1995. Civil Society in the Arab World: Private Voluntary Organizations. Washington, DC: CIVICUS.

Kishor, Sunita. 1997. "Empowerment of women in Egypt and links to the survival and health of their infants," paper presented at the International Union for the Scientific Study of Population Seminar on Female Empowerment and Demographic Processes: Moving Beyond Cairo, 21-24 April, Lund.

Kishor, Sunita and Katherine Neitzel. 1996. The Status of Women: Indicators for Twenty-Five Countries. Demographic and Health Surveys Comparative Studies No. 21. Calverton, MD: Macro International Inc.

Kreager, Philip. 1991. "Early modern population theory: A reassessment," Рориlation and Development Review 17, no. 2: 207-227.

Lesthaeghe, Ron. 1980. "On the social control of human reproduction," Population and Development Review 6, no. 4: 527-548.

Lloyd, Cynthia B. 1991. "The contribution of the World Fertility Surveys to an understanding of the relationship between women's work and fertility," Studies in Family Planning 22, no. 3: 144-161.

Mason, Karen Oppenheim. 1985. The Status of Women: A Review of Its Relationships to Fertility and Mortality. New York: The Rockefeller Foundation.

. 1986. "The status of women: Conceptual and methodological issues in demographic studies," Sociological Forum 1, no. 2: 284-300.

- 1996. "Wives' economic decision-making power in the family in five Asian countries," East-West Center Working Papers, Population Series No. 86. Honolulu: East-West Center.

1997a. "Explaining fertility transitions," Demography 34, no. 4: 443-454.

. 1997b. "Gender and demographic change: What do we know?" in Gavin W. Jones, Robert M. Douglas, John C. Caldwell, and Rennie M. D’Souza (eds.), The Continuing Demographic Transition. Oxford: Clarendon Press, pp. 158-182. 
Mason, Karen Oppenheim and Rodolfo A. Bulatao. 1998. "Gender and family systems in the fertility transition," paper presented at the Rockefeller Foundation Conference on the Global Fertility Transition, 18-22 May, Bellagio.

Mauldin, W. Parker and Sheldon J. Segal. 1988. "Prevalence of contraceptive use: Trends and issues," Studies in Family Planning 19, no. 6: 335-353.

McNicoll, Geoffrey. 1998. "Government and fertility in transitional and posttransitional societies," Policy Research Division Working Paper No. 113. New York: Population Council.

Mitra, S.N. et al. 1994. Bangladesh Demographic and Health Survey, 1993-1994. Calverton, MD: National Institute for Population Research and Training, Mitra and Associates, and Macro International.

Mitra, S.N., Ahmed Al-Sabir, Anne R. Cross, and Kanta Jamil. 1997. Bangladesh Demographic and Health Survey, 1996-1997. Calverton, MD: National Institute for Population Research and Training, Mitra and Associates, and Macro International.

Morgan, S. Philip and Bhanu B. Niraula. 1995. "Gender inequality and fertility in two Nepali villages," Population and Development Review 21, no. 3: 541-561.

Mostafa, Golam et al. 1996. "Demographic Surveillance System, Matlab, volume 27: Registration of demographic events, 1995," Scientific Report No. 79. Dhaka: International Centre for Diarrhoeal Disease Research, Bangladesh.

Naguib, Nora Guhl and Cynthia B. Lloyd. 1994. Gender Inequalities and Demographic Behavior: Egypt. New York: Population Council.

Nawar, Laila, Cynthia B. Lloyd, and Barbara Ibrahim. 1995. "Women's autonomy and gender roles in Egyptian families," in Carla Makhlouf Obermeyer (ed.), Family, Gender, and Population in the Middle East: Policies in Context. Cairo: American University in Cairo Press, pp. 147-178. 
Niraula, Bhanu B. and S. Philip Morgan. 1996. "Marriage formation, post-marital contact with natal kin, and autonomy of women: Evidence from two Nepali settings," Population Studies 50, no. 1: 35-50.

Obermeyer, Carla Makhlouf. 1995. "Introduction: A region of diversity and change," in Carla Makhlouf Obermeyer (ed.), Family, Gender, and Population in the Middle East: Policies in Context. Cairo: American University in Cairo Press, pp. 1-15.

Phillips, James F. and Mian Bazle Hossain. 1998. "The impact of family planning household service delivery on women's status in Bangladesh," Policy Research Division Working Paper No. 118. New York: Population Council.

Population Council. 1996. The Unfinished Transition. Population Council Issues Papers. New York: Population Council.

Rahman, Hossain Zillur. 1996. "Bangladesh at 25: Dynamics of electoral politics," paper presented at the Conference Bangladesh at 25, 5-7 December, Columbia University, New York.

Rahman, Rushidan Islam. 1993. "A review of the findings of Labour Force Survey, 1989 and their analytical basis," Bangladesh Development Studies 21, no. 1: 29-40.

Richards, Alan. 1982. Egypt's Agricultural Development, 1800-1980: Technical and Social Change. Boulder, CO: Westview Press.

Robinson, Warren C. and Fatma H. El-Zanaty. Forthcoming. "The impact of policy and program on fertility in Egypt: The Egyptian family planning success story."

Rosero-Bixby, Luis and John B. Casterline. 1994. "Interaction diffusion and fertility transition in Costa Rica," Social Forces 73, no. 2: 435-462.

Sayed, Hussein Abdel-Aziz, Magued I. Osman, Fatma El-Zanaty, and Ann A. Way. 1989. Egypt Demographic and Health Survey, 1988. Columbia, MD: National Population Council of Egypt and Institute for Resource Development/Macro Systems. 
Schuler, Sidney Ruth, Syed M. Hashemi, Amy Cullum, and Mirza Hassan. 1996. "The advent of family planning as a social norm in Bangladesh: Women's experiences," Reproductive Health Matters 7: 66-78.

Schuler, Sidney Ruth, Syed M. Hashemi, and Hendrix Jenkins. 1995. "Bangladesh's family planning success story: A gender perspective," International Family Planning Perspectives 21, no. 4: 132-137.

Shafey, Halla E. 1998. Adolescence and State Policy in Egypt. Cairo: Population Council.

Siddiqi, Dina M. 1991. "Discipline and protect: Women factory workers in Bangladesh," Grassroots: An Alternative Development Journal 1, no. 2: 42-49.

Simmons, Ruth, Rezina Mita, and Michael A. Koenig. 1992. "Employment in family planning and women's status in Bangladesh," Studies in Family Planning 23, no. 2: 97-109.

Sobhan, Rehman. 1995. Experience with Economic Reform: A Review of Bangladesh's Development. Dhaka: University Press.

Srinivasan, K. 1995. Regulating Reproduction in India's Population: Efforts, Results, and Recommendations. New Delhi: Sage Publications.

Steele, Fiona, Sajeda Amin, and Ruchira T. Naved. 1998. "The impact of an integrated micro-credit program on women's empowerment and fertility behavior in rural Bangladesh," Research Division Working Paper No. 115. New York: Population Council.

Terterov, Marat. 1996. "Lessons from political liberalization," Civil Society, Democratic Transformation in the Arab World 5, no. 54: 19-23.

United Nations. 1982. National Accounts Statistics: Analysis of Main Aggregates, 1982. New York: United Nations.

. 1985. "Women's employment and fertility: A comparative analysis of World Fertility Survey results for 38 developing countries," Department 
of International Economic and Social Affairs/Population Studies No. 96. New York: United Nations.

1987. "Fertility behaviour in the context of development: Evidence from the World Fertility Survey,” Population Studies No. 100. New York: United Nations.

. 1994. "Report of the International Conference on Population and Development, 5-13 September, 1994, Cairo, Egypt." New York: United Nations.

- 1995a. Women's Education and Fertility Behavior: Recent Evidence from the Demographic and Health Surveys. New York: United Nations Population Division.

- 1995b. World Urbanization Prospects: The 1994 Revision. New York: United Nations.

. 1995c. The World's Women, 1995: Trends and Statistics. New York: United Nations.

United Nations Development Programme (UNDP). 1996. Human Development Report 1996. New York: Oxford University Press.

— . 1997. Human Development Report 1997. New York: Oxford University Press.

Weinberger, Mary Beth, Cynthia B. Lloyd, and Ann K. Blanc. 1989. "Women's education and fertility: A decade of change in four Latin American countries," International Family Planning Perspectives 15, no. 1: 4-14, 28. 


\title{
POLICY RESEARCH DIVISION WORKING PAPERS
}

\author{
Recent Back Issues
}

1996

*83 Sajeda Amin, Ian Diamond, and Fiona Steele, "Contraception and religious practice in Bangladesh."

84 John B. Casterline, Aurora E. Perez, and Ann E. Biddlecom, "Factors underlying unmet need for family planning in the Philippines."

85 Geoffrey McNicoll, "Governance of fertility transition: Regularity and duress."

*86 John Bongaarts, "Population pressure and the food supply system in the developing world."

87 Sajeda Amin, "Family structure and change in rural Bangladesh."

*88 John Bongaarts and Susan Cotts Watkins, "Social interactions and contemporary fertility transitions."
*89 Cynthia B. Lloyd and Mark R. Montgomery, "The consequences of unintended fertility for investments in children: Conceptual and methodological issues."

* 90 Zeba Sathar and Sonalde Desai, "Work patterns in rural Pakistan: Intersections between gender, family, and class."

*91 Mark R. Montgomery, "Learning and lags in mortality perceptions."

92 Ann E. Biddlecom, John B. Casterline, and Aurora E. Perez, "Men's and women's views of contraception."
93 James F. Phillips, Fred N. Binka, Martin Adjuik, Alex Nazzar, and Kubaze Frank Adazu, "The determinants of contraceptive innovation: A case-control study of family planning acceptance in a traditional African society."
94 John Bongaarts and Sajeda Amin, "Prospects for fertility decline and implications for population growth in South Asia."

95 Barbara S. Mensch and Cynthia B. Lloyd, "Gender differences in the

* No longer available 
schooling experiences of adolescents in low-income countries: The case of Kenya."

96 Martin Brockerhoff and Ellen Brennan, "The poverty of cities in the developing world."

*97 Carol E. Kaufman, "Reproductive control in South Africa."

98 John Bongaarts, "Trends in unwanted childbearing in the developing world."

99 Mary Arends-Kuenning, "How do family planning workers' visits affect women's contraceptive behavior in Bangladesh?"

100 Mark R. Montgomery and Cynthia B. Lloyd, "Excess fertility, unintended births, and children's schooling."
101 Mary Arends-Kuenning, "The equity and efficiency of doorstep delivery of contraceptives in Bangladesh."

*102 Sajeda Amin, Ian Diamond, Ruchira T. Naved, and Margaret Newby, "Transition to adulthood of female factory workers: Some evidence from Bangladesh."

*103 Margaret E. Greene and Ann E. Biddlecom, "Absent and problematic men: Demographic accounts of male reproductive roles."

104 Michael P. Todaro, "Urbanization, unemployment, and migration in Africa: Theory and policy."

105 Geoffrey McNicoll, "Population and poverty: A review and restatement."
106 Sajeda Amin and Gilda Sedgh, "Incentive schemes for school attendance in rural Bangladesh."

107 Martin Brockerhoff and Paul Hewett, "Ethnicity and child mortality in subSaharan Africa."

108 Ann E. Biddlecom and Bolaji M. Fapohunda, "Covert contraceptive use: Prevalence, motivations, and consequences."

109 John Bongaarts and Griffith Feeney, "On the quantum and tempo of fertility."
110 Barbara S. Mensch, Daniel Bagah, Wesley H. Clark, and Fred Binka, "The changing social environment for adolescents in the Kassena-Nankana District of northern Ghana: Implications for reproductive behavior."

111 Martin Brockerhoff and Ann Biddlecom, "Migration, sexual behavior, and HIV diffusion in Kenya."

112 Zeba A. Sathar and John B. Casterline, "The onset of fertility transition in Pakistan." 
113 Geoffrey McNicoll, "Government and fertility in transitional and post-transitional societies."

114 John Bongaarts, "Fertility and reproductive preferences in post-transitional societies."

115 Fiona Steele, Sajeda Amin, and Ruchira T. Naved, "The impact of an integrated micro-credit program on women's empowerment and fertility behavior in rural Bangladesh."
116 Cynthia B. Lloyd, Barbara S. Mensch, and Wesley H. Clark, "The effects of primary school quality on the educational participation and attainment of Kenyan girls and boys."

117 Sajeda Amin and Cynthia B. Lloyd, "Women's lives and rapid fertility decline: Some lessons from Bangladesh and Egypt." 